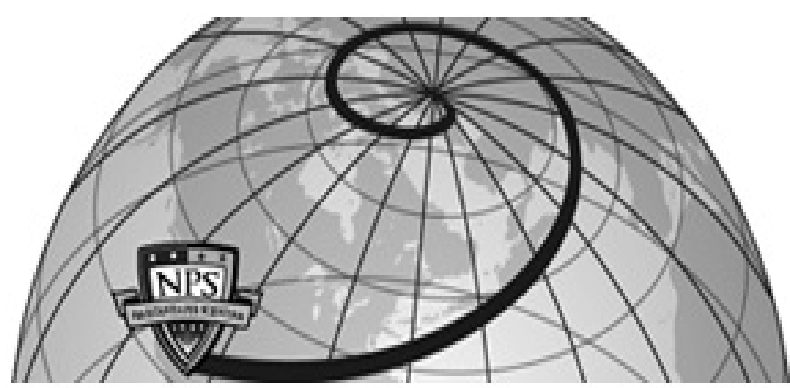

Calhoun: The NPS Institutional Archive DSpace Repository

\title{
Assessment of the use of portals to reduce excess material in Afloat Logistics Systems
}

Kalvig, Joanna D.

Monterey, California. Naval Postgraduate School

https://hdl.handle.net/10945/10787

This publication is a work of the U.S. Government as defined in Title 17, United States Code, Section 101. Copyright protection is not available for this work in the United States.

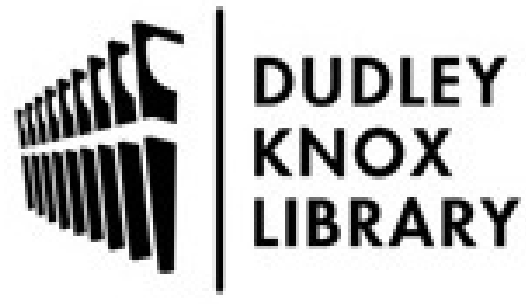

http://www.nps.edu/library
Calhoun is the Naval Postgraduate School's public access digital repository for research materials and institutional publications created by the NPS community. Calhoun is named for Professor of Mathematics Guy K. Calhoun, NPS's first appointed -- and published -- scholarly author.

Dudley Knox Library / Naval Postgraduate School 411 Dyer Road / 1 University Circle Monterey, California USA 93943 


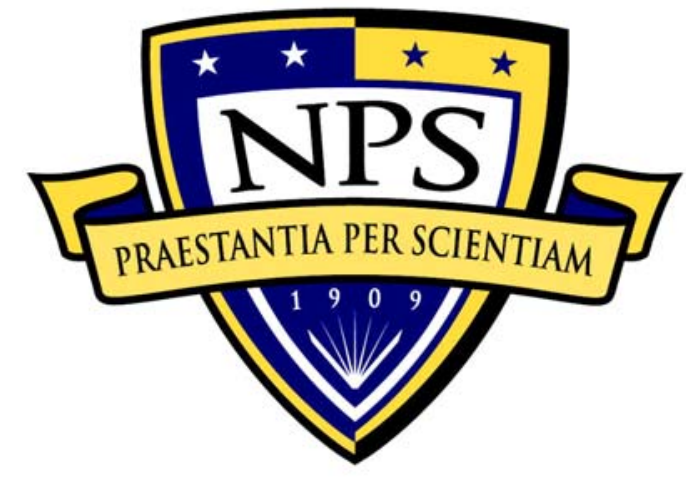

\section{NAVAL \\ POSTGRADUATE SCHOOL}

MONTEREY, CALIFORNIA

\section{MBA PROFESSIONAL REPORT}

Assessment of the Use of Portals to Reduce

Excess Material in Afloat Logistics Systems

By: Joanna D. Kalvig

March 2011

Advisors: $\quad$ Glenn R. Cook,

Douglas E. Brinkley 
THIS PAGE INTENTIONALLY LEFT BLANK 
Public reporting burden for this collection of information is estimated to average 1 hour per response, including the time for reviewing instruction, searching existing data sources, gathering and maintaining the data needed, and completing and reviewing the collection of information. Send comments regarding this burden estimate or any other aspect of this collection of information, including suggestions for reducing this burden, to Washington headquarters Services, Directorate for Information Operations and Reports, 1215 Jefferson Davis Highway, Suite 1204, Arlington, VA 22202-4302, and to the Office of Management and Budget, Paperwork Reduction Project (0704-0188) Washington DC 20503.

\begin{tabular}{|l|c|c}
\hline 1. AGENCY USE ONLY (Leave blank) & $\begin{array}{c}\text { 2. REPORT DATE } \\
\text { March } 2011\end{array}$ & $\begin{array}{c}\text { 3. REPORT TYPE AND DATES COVERED } \\
\text { MBA Professional Report }\end{array}$ \\
\hline
\end{tabular}

4. TITLE AND SUBTITLE Assessment of the Use of Portals to Reduce Excess

5. FUNDING NUMBERS

Material in Afloat Logistics Systems

6. AUTHOR(S) Joanna D. Kalvig

7. PERFORMING ORGANIZATION NAME(S) AND ADDRESS(ES)

Naval Postgraduate School

Monterey, CA 93943-5000

9. SPONSORING /MONITORING AGENCY NAME(S) AND ADDRESS(ES) N/A

8. PERFORMING ORGANIZATION REPORT NUMBER

10. SPONSORING/MONITORING AGENCY REPORT NUMBER

11. SUPPLEMENTARY NOTES The views expressed in this thesis are those of the author and do not reflect the official policy or position of the Department of Defense or the U.S. Government. IRB Protocol number $\mathrm{N} / \mathrm{A}$

12a. DISTRIBUTION / AVAILABILITY STATEMENT

Approved for public release; distribution is unlimited

12b. DISTRIBUTION CODE

13. ABSTRACT (maximum 200 words)

The purpose of this project is to assess the benefit of utilizing portals to manage and reduce excess materials in the Afloat Logistics System (ALS). Through this process, this report shall identify: 1) What IT system(s) are currently in use for managing excess material in ALS; 2) What policies are present for managing excess material in the current ALS; 3) What benefit might portals add to the management of excess material in ALS; and 4) What impact might this portal have on preventing future excess material in ALS. The Navy's Afloat Logistics System (ALS), composed of 30 Oliver Hazard Perry class Frigates and 57 Arleigh Burke class Destroyers, is overburdened with excess material. Currently, the combined 87 ships contain over 228,000 line items of excess material within their logistics systems. This report looks at the supply chain and the effects of excess material, the current systems used to manage excess material, the issues dampening the success of current excess-material management systems, and the possible uses of portals to streamline the excess-material management systems.

\begin{tabular}{|c|c|c|c|}
\hline \multicolumn{3}{|c|}{ 14. SUBJECT TERMS Supply chain; excess material; RRAM; web portals } & $\begin{array}{l}\text { 15. NUMBER OF } \\
\text { PAGES } \\
\text { 16. PRICE CODE }\end{array}$ \\
\hline $\begin{array}{l}\text { 17. SECURITY } \\
\text { CLASSIFICATION OF } \\
\text { REPORT } \\
\quad \text { Unclassified }\end{array}$ & $\begin{array}{l}\text { 18. SECURITY } \\
\text { CLASSIFICATION OF THIS } \\
\text { PAGE } \quad \text { Unclassified }\end{array}$ & $\begin{array}{l}\text { 19. SECURITY } \\
\text { CLASSIFICATION OF } \\
\text { ABSTRACT } \\
\quad \text { Unclassified }\end{array}$ & $\begin{array}{l}\text { 20. LIMITATION OF } \\
\text { ABSTRACT } \\
\text { UU }\end{array}$ \\
\hline
\end{tabular}


THIS PAGE INTENTIONALLY LEFT BLANK 
Approved for public release; distribution is unlimited

\title{
ASSESSMENT OF THE USE OF PORTALS TO REDUCE EXCESS MATERIAL IN AFLOAT LOGISTICS SYSTEMS
}

\author{
Joanna D. Kalvig, Lieutenant Commander, United States Navy
}

Submitted in partial fulfillment of the requirements for the degree of

MASTER OF BUSINESS ADMINISTRATION

from the

NAVAL POSTGRADUATE SCHOOL

March 2011

Author:

Joanna D. Kalvig

Approved by:

Glenn R. Cook, Lead Advisor

Douglas E. Brinkley, Support Advisor

William R. Gates, Dean

Graduate School of Business and Public Policy 
THIS PAGE INTENTIONALLY LEFT BLANK 


\title{
ASSESSMENT OF THE USE OF PORTALS TO REDUCE EXCESS MATERIAL IN AFLOAT LOGISTICS SYSTEMS
}

\begin{abstract}
The purpose of this project is to assess the benefit of utilizing portals to manage and reduce excess materials in the Afloat Logistics System (ALS). Through this process, this report shall identify: 1) What IT system(s) are currently in use for managing excess material in ALS; 2) What policies are present for managing excess material in the current ALS; 3) What benefit might portals add to the management of excess material in ALS; and 4) What impact might this portal have on preventing future excess material in ALS. The Navy's Afloat Logistics System (ALS), composed of 30 Oliver Hazard Perry class Frigates and 57 Arleigh Burke class Destroyers, is overburdened with excess material. Currently, the combined 87 ships contain over 228,000 line items of excess material within their logistics systems. This report looks at the supply chain and the effects of excess material, the current systems used to manage excess material, the issues dampening the success of current excess-material management systems, and the possible uses of portals to streamline the excess-material management systems.
\end{abstract}


THIS PAGE INTENTIONALLY LEFT BLANK 


\section{TABLE OF CONTENTS}

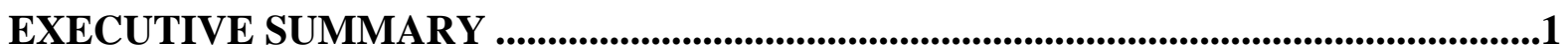

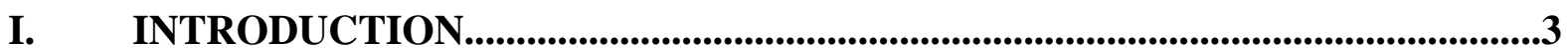

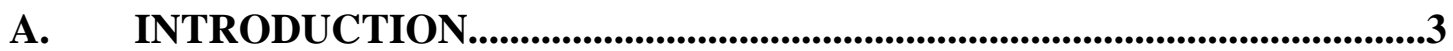

B. BACKGROUND ..............................................................................................

C. PROJECT SCOPE.........................................................................................3

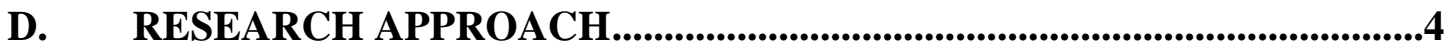

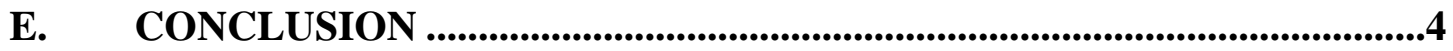

II. BACKGROUND AND LITERATURE REVIEW ................................................5

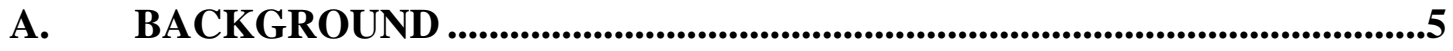

1. The Naval Supply System at a Glance ...........................................5

a. Afloat Logistics System (ALS) .............................................5

b. Naval Supply Systems Command (NAVSUP).........................6

c. Naval Inventory Control Point (NAVICP)............................7

d. $\quad$ Fleet and Industrial Supply Centers (FISCs) ..........................8

e. Defense Logistics Agency (DLA)............................................10

2. How Material Arrives to Afloat Logistics Systems........................12

a. Federal Catalog System .......................................................12

b. $\quad$ Federal Supply Classification System (FSC).........................12

c. Cognizance Symbols ..................................................................12

d. National Stock Number (NSN)..........................................13

e. $\quad$ Federal Logistics Data (FEDLOG) .................................13

f. Allowance Lists ..................................................................14

g. Coordinated Shipboard Allowance Lists (COSALS) ..............14

h. Requirements Identified..........................................................15

B. SUPPLY CHAIN MANAGEMENT (SCM) ..........................................15

1. Basics of SCM............................................................................15

2. Supply Chain Elements ...............................................................18

a. Production ....................................................................................18

b. Inventory ................................................................................19

c. Location.......................................................................20

d. Transportation.................................................................20

e. Information .......................................................................21

3. Aligning the Supply Chain ......................................................................23

4. Bullwhip Effect...........................................................................................24

C. LITERATURE REVIEW .....................................................................25

1. Introduction..........................................................................25

2. Dell......................................................................................27

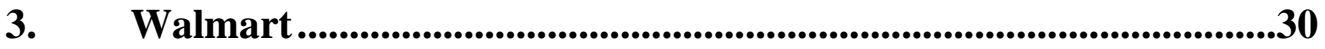

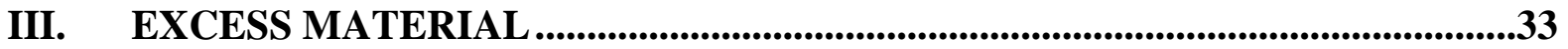

A. HOW AFLOAT LOGISTICS SYSTEMS GENERATE EXCESS MATERIAL 
1. Allowance Procedures .............................................................................33

2. Configuration Changes - Addition of Equipment ...............................33

3. Configuration Changes - Removal of Equipment ..............................34

4. Unit of Issue Errors .....................................................................................34

B. ALS MANAGEMENT OF EXCESS MATERIAL ........................................35

1. Relational Supply (RSUPPLY)............................................................35

2. Material Turned Into Stores (MTIS) ....................................................35

3. Realtime Reutilization Asset Management (RRAM)........................35

C. WHAT IS BEING DONE TO REDUCE EXCESS MATERIAL ...............36

1. Current Excess Levels ..........................................................................36

2. Realtime Reutilization Asset Management (RRAM).........................36

D. WHAT IS THE PROBLEM WITH THE CURRENT SYSTEM? .............37

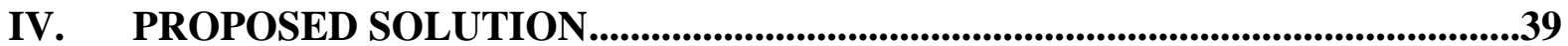

A. PREVENTING MORE - USING CURRENT SYSTEM ............................39

B. TRYING TO IDENTIFY ......................................................................40

C. WEB PORTALS ............................................................................................41

D. POSSIBLE ISSUES TO THE SUCCESS OF PORTALS ............................44

1. Obsolete Parts..........................................................................................44

2. Systems Sold to Foreign Navies ...............................................................45

V. SUMMARY, CONCLUSION AND RECOMMENDATIONS.................................47

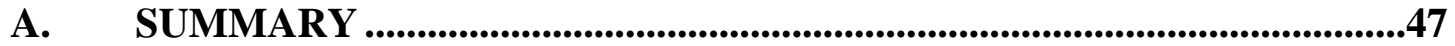

B. CONCLUSION AND RECOMMENDATIONS.............................................47

C. RECOMMENDATIONS FOR FURTHER RESEARCH .............................49

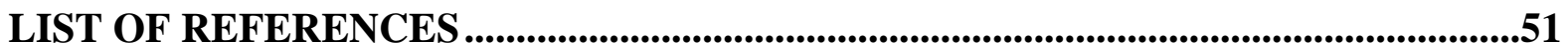

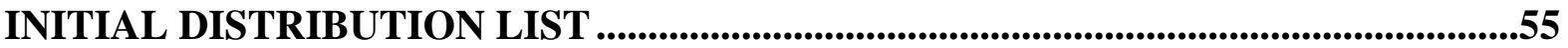




\section{LIST OF FIGURES}

Figure 1. Geographical Responsibility of FISCs (From NAVSUP P-486, 2005, p. 3005) 10

Figure 2. $\quad$ Hierarchy of Navy Supply System ...............................................................11

Figure 3. $\quad$ Key Players in Supply Chains (From DeAngelis, 2011) .................................16

Figure 4. Responsiveness Versus Efficiency (From Hugos, 2002).................................22

Figure 5. $\quad$ Supply Chain Capabilities (From Hugos, 2002)............................................23

Figure 6. Bullwhip Effect on Supply Chain (From Federal Reserve Bank of Dallas,

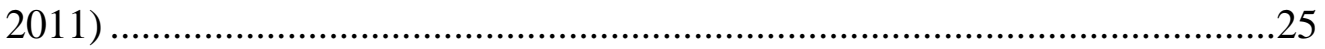

Figure 7. Pros and Cons of Just-in-Time Inventory (From Shukla, 2010)......................26

Figure 8. $\quad$ Pros and Cons of Vendor Managed Inventory (From Evanko, 2010) .............29

Figure 9. Dell's Direct Model (From Federal Reserve Bank of Dallas, 2011) ................30

Figure 10. Walmart's Logistics System (From Global Text Project, 2010) .......................31

Figure 11. The Position of Information Management (From Chang, 2007) ......................42 
THIS PAGE INTENTIONALLY LEFT BLANK 


\section{LIST OF ACRONYMS AND ABBREVIATIONS}

3PL Third Party Logistics

AEL Allowance Equipage Lists

ALS Afloat Logistics System

ANSRS Automated Non-Standard Requisitoning System

APL Allowance Parts List

ASO Aviation Supply Office

AT Allowance Type

CARGO Consolidated Afloat Requisitioning Guide

COMFISCS Commander, Fleet and Industrial Supply Center

COSAL Coordinated Shipboard Allowance List

CSCMP Council of Supply Chain Management Professionals

DBI Demand Based Inventory

DD Defense Depot

DESC Defense Energy Support Center

DLA Defense Logistics Agency

DSCC Defense Supply Center Columbus

DSCP Defense Supply Center Philadelphia

DSCR Defense Supply Center Richmond

EMRM Equipment Maintenance Related Material

EMV Extended Money Value

EWP Enterprise Web Portal

FEDLOG Federal Logistics Data

FISC Fleet Industrial Supply Center

FSC $\quad$ Federal Supply Classification

HME Hull, Maintenance, and Electrical

IMM Integrated Material Manager

IPG Issue Priority Group

ISL Integrated Stock List

JIT Just-in-Time

MAM Maintenance Assistance Modules 


\begin{tabular}{|c|c|}
\hline MTIS & Material Turned into Stores \\
\hline NAVAIR & Naval Air Systems Command \\
\hline NAVFAC & Naval Facilities Engineering Command \\
\hline NAVICP & Naval Inventory Control Point \\
\hline NAVSEA & Naval Sea Systems Command \\
\hline NAVSUP & Naval Supply Systems Command \\
\hline $\mathrm{NC}$ & Not carried Onboard \\
\hline NIS & Not in Stock \\
\hline $\mathrm{NSN}$ & National Stock Number \\
\hline OMMS-NG & Organizational Maintenance Management System-Next Generation \\
\hline OPTAR & Operating Target \\
\hline OSI & Operating Space Items \\
\hline RRAM & Realtime Reutilization Asset Management \\
\hline RSUPPLY & Relational Supply \\
\hline SCM & Supply Chain Management \\
\hline SKU & Store Keeping Unit \\
\hline SOPAL & Summary of Allowance Parts/Equipage/Components Lists \\
\hline SPAWAR & Space and Naval Warfare Systems Command \\
\hline SPCC & Ships Parts Control Center \\
\hline SRI & Storeroom Items \\
\hline TAV & Total Asset Visibility \\
\hline TYCOM & Type Commander \\
\hline VMI & Vendor-Managed Inventory \\
\hline
\end{tabular}




\section{ACKNOWLEDGMENTS}

I want to thank Odin for the gift of knowledge, Thor for the gift of strength, and most of all, Freya, for the gift of perseverance.

I would also like to thank Mr. Cook for his guidance and encouragement during this process, but mostly for his patience and understanding that not all things are intuitive. 
THIS PAGE INTENTIONALLY LEFT BLANK

xiv 


\section{EXECUTIVE SUMMARY}

The Navy's Afloat Logistics System (ALS), composed of 30 Oliver Hazard Perry class Frigates and 57 Arleigh Burke class Destroyers, is overburdened with excess material. Currently, the combined 87 ships contain over 228,000 line items of excess material within their logistics systems. This report looks at the supply chain and the effects of excess material, the current systems used to manage excess material, the issues dampening the success of current excess-material management systems, and the possible uses of portals to streamline the excess-material management systems. Based on research conducted on the supply chain of ALS, this report offers web portals as a possible solution for the excess material problem. This solution will provide an integrated alternative that automatically scans multiple databases to determine if requisitioned parts are available in excess material or if substitute items are available in excess material inventories. 
THIS PAGE INTENTIONALLY LEFT BLANK 


\section{INTRODUCTION}

\section{A. INTRODUCTION}

The Navy's Afloat Logistics System (ALS), composed of 30 Oliver Hazard Perry class Frigates and 57 Arleigh Burke class Destroyers, is overburdened with excess material. According to conversations with Mr. Steven Weir from Naval Supply Systems Command, Code 41, the combined 87 ships contain over 228,000 line items of excess material within their logistics systems. This report looks at the supply chain and the effects of excess material, the current systems used to manage excess material, the issues dampening the success of current excess-material management systems, and the possible uses of portals to streamline the excess-material management systems.

\section{B. BACKGROUND}

This research report originated to investigate the growing excess material levels in the fleet. It deals with determining what the parts of the current supply chain are, and what systems are currently in use to address the growing excess material situation. Over the past ten years, the amount of excess material has grown. There has been implementation of a commercial-off-the-shelf software product to address the situation, but even with the implementation of the software, the number of excess material line items in the ALS is over 200,000. Further investigation into the excess material is necessary to determine why the current system is not able to aid in reducing excess material levels.

\section{PROJECT SCOPE}

This research paper addresses the procedure and systems used in the ALS to identify and reduce current excess material levels. As the push for reduction in overhead costs is imposed upon the military, it is imperative for costs associated with excess material be reduced and, if possible, eliminated.

This report focuses on the issues plaguing the current system used to manage excess material, the policies associated with those systems, and the possible corrections 
to the current system to improve its effectiveness. In addition, possible implementation of a web portal as an alternative approach to correcting the excess material is discussed.

\section{RESEARCH APPROACH}

The research of the excess material was initiated with an in-depth exploration of the current supply chain used in the Navy to supply the ALS. Current procedures and software were then researched to determine the process to be used for reducing excess material. Finally, web portals were explored as a possible solution to excess material. The portal's capabilities and limitations were studied to determine the impact they could provide.

\section{E. CONCLUSION}

This chapter identifies the purpose, background, scope and necessity behind the research. The chapters that follow will provide the background of the Naval Supply System, the basics of supply chain management, a literature review, an evaluation of current excess material systems and procedures, and an examination on the use of web portals to mitigate excess material levels. 


\section{BACKGROUND AND LITERATURE REVIEW}

\section{A. BACKGROUND}

\section{The Naval Supply System at a Glance}

The Naval Supply System utilized by the Afloat Logistics System (ALS) comprises four major commands: Naval Supply Systems Command (NAVSUP), Naval Inventory Control Points (NAVICP), Fleet and Industrial Supply Centers (FISC), and the Defense Logistics Agency (DLA). Each provides succinct procurement value that enables the ALS to function in its high-paced logistics environment. The hierarchal structure of the Naval Supply System is depicted in Figure 2.

\section{a. Afloat Logistics System (ALS)}

The Afloat Logistics System is composed of 30 Oliver Hazard Perry class Frigates and 57 Arleigh Burke class Destroyers. (While this does not fundamentally exclude other surface platforms, those other platforms are outside the scope of this research.) The Frigate's main mission is to fulfill a Protection of Shipping mission for amphibious expeditionary forces, underway replenishment groups and merchant convoys. Battle tough, the Frigate has proven its staying power when the USS Samuel B. Roberts (FFG-58) struck a mine and when the USS Stark (FFG-31) was hit by two cruise missiles. Both were repaired and returned to the fleet for continued missions (U.S. Navy Fact File, 2010).

Destroyers have a more illustrious mission to fulfill. They provide multimission offensive and defensive capabilities, either on independent duty or with a battle group. Their Anti-Air Warfare, Anti-Submarine Warfare, and Anti-Surface Warfare capabilities have greatly expanded the role of naval vessels in strike warfare through the use of extremely sophisticated weapon systems such as the Vertical Launch System (U.S. Navy Fact File, 2010). 


\section{b. Naval Supply Systems Command (NAVSUP)}

Naval Supply Systems Command, headquartered in Mechanicsburg, Pennsylvania, is one of five Systems Commands that report to the Chief of Naval Operations. The other four commands are Naval Air Systems Command (NAVAIR), Naval Sea Systems Command (NAVSEA), Space and Naval Warfare Systems Command (SPAWAR), and Naval Facilities Engineering Command (NAVFAC). In 1966, the Secretary of the Navy ordered the above Systems Command to be created. NAVSUP was created in response to this realignment requirement from the old Bureau of Supplies and Accounts (Global Security, 2011).

As the Navy's single supply manager, NAVSUP oversees the entire Navy Supply System from ship to shore. The functions of NAVSUP include providing supply management policies and methods (technical guidance), providing staff assistance to the Assistant Secretary of the Navy (Shipbuilding and Logistics), and performing supply, distribution, disposal, transportation, receipt, storage and issue functions (NAVSUP P485, 2005, p. 1007).

NAVSUP is responsible for the development and supervision of the Navy Supply System as an integrated and comprehensive entity (NAVSUP, 2010). The primary mission for now and the immediate future is to "deliver combat capability through logistics" (NAVSUP, 2010). Through the combination of supply operations, contracting, resale, information systems, fuel, conventional ordnance, transportation, support services, and security assistance, NAVSUP is able to provide uninterrupted service for ALS and shore commands worldwide.

According to the Commander of NAVSUP, the overall supply system is executed along three basic business lines: weapon system support, global logistics support, and sailor and family support. Strategies that affect the weapons system support functions are supporting ballistic missile defense, implementing Navy enterprise resource planning, integrating enterprise business processes and systems, consolidating acquisition logistics functions, protection from cyber threats, and improving inventory management practices. Strategies that affect the global logistics support function are advancing global 
logistics support execution, supporting naval logistics integration, developing multinational partnerships, standardizing global husbanding contracts, supporting littoral combat ships, and enhancing Navy transportation and distribution processes. Strategies that affect the sailor and family support functions are collaborating with other Military Exchange systems, expanding the use of social media, expanding the web store capability of the Navy Exchange, partnering with Commander, Naval Installations Command, to enhance Exchange and Morale, Welfare, and Recreation programs, and developing a long-term vision for afloat and ashore galleys (Commander’s Guidance, 2011).

NAVSUP breaks down into supply and distribution systems composed of inventory managers, distribution activities, and methods of operation that function on the basis of centralized control of item assets. Their main objectives are responsive and efficient material support of the operating forces of the Navy, the hardware systems commands, and other offices and organizations (NAVSUP, 2010).

\section{c. Naval Inventory Control Point (NAVICP)}

The Naval Inventory Control Point (NAVICP) is a result of merging the Aviation Supply Office (ASO) in Philadelphia and Ships Parts Control Center (SPCC) in Mechanicsburg in 1995. The ASO was founded in 1941 with the main function of supporting aviation weapon systems. The SPCC was founded in 1945 to provide a single location to manage ship parts (NAVSUP, 2010). NAVICP falls under the direct cognizance of the Commander, Naval Supply Systems Command.

The main responsibility of NAVICP is to function as the primary inventory control for Navy, Marine Corps, and Allied Forces' weapons systems. NAVICP also "exercises control for over 350,000 different line item of repair parts, components and assemblies that keep ships, aircraft and weapons operating” (Global Security, 2011). In addition, NAVICP has the unique job to apply managerial supervision necessary for the total integration of the actions involved in computation of quantitative and monetary requirements, initiation of procurement and disposal action, the positioning and repositioning of material, and the development of worldwide quantitative and monetary inventory data (NAVSUP, 2010). 
The NAVICP utilizes shore supply activities as a distribution system in which to hold and manage material. The Navy ashore supply activity will provide the NAVICP with transaction reports listing the required material allowing the NAVICP to distribute to appropriate shore site. In order to support the ALS material requirement, the NAVICP stock management ensures material has been positioned at various Navy ashore supply activities (e.g., FISCs, Naval Air Stations, Trident Refit Facility, and Contractor warehouses), retain inventory control of material through an extensive stock reporting system, and provide technical assistance and cataloging services to the supply system (and to its customers) (NAVSUP P-485, 2005, p. 1072.3).

\section{d. $\quad$ Fleet and Industrial Supply Centers (FISCs)}

Fleet and Industrial Supply Centers (FISCs) fall under the command of Commander, Fleet and Industrial Supply Centers (COMFISCS) located in San Diego, California. COMFISCS is a stand-alone, flag-level Echelon III command in San Diego. Under COMFISCS direct supervision are seven FISCs located in:

- Jacksonville, Florida

- Norfolk, Virgina

- Pearl Harbor, Hawaii

- Puget Sound, Washington

- San Diego, California

- Sigonella, Italy

- Yokosuka, Japan

Originally created in 2006 via a CNO's directive, the primary focus of COMFISCS is on global logistics and contracting issues and driving best practices across the seven FISCs under his purview. In addition, COMFISCS serves as Assistant Commander for Navy Expeditionary Combat Enterprise Support providing logistics and as the lead for NAVSUP's operational alignment initiative supporting the fleet and assisting in the alignment of NAVSUP's planning, training, and exercise engagement efforts (NAVSUP, 2010).

To elaborate on COMFISCS' primary mission, it is more specifically to provide global logistics and husbanding services, regional transportation services, integrated logistics services, material management services, warehousing services, 
household goods services, postal services, plant and minor property management, bulk petroleum, oil and lubricants and fuels services, and hazardous material management services (COMFISCINST 5450.1, 2008, pp. 4-8). COMFISCS also supports the execution of the Naval material supply chain by providing inventory management, warehousing, and transportation; contracting services; foreign material sales case management services for the Naval Sea Systems Command ship transfers; and quality of life program management through the Navy Food Management Team, Navy Cash Program, the Subsistence Prime Vendor, and the Ships Stores Program (COMFISCINST 5450.1, 2008, pp. 4-8).

The individual FISCs manage consumer end-use material, determining inventory levels, and procure, receive, stow, issue, ship and deliver material to the consumer (NAVSUP P-485, 2005, p. 1009). The ALS sends requisitions to the FISC for fulfillment. If the FISC has the requisitioned item in stock, they will issue the material. If the item is not in stock or is not carried by the FISC, the requisition is sent to NAVICP for fulfillment or procurement. FISCs are also in charge of SERVMARTS. SERVMARTS are a Third Party Logistics (3PL) initiative. The main purpose of the 3PL Program is to allow sailors and marines with continuous and express access to vendors of office and other consumable materials and goods, while reducing the time necessary for delivery, consolidating and compressing warehousing needs, inventory and other related costs (NAVSUP, 2010).

FISCs provide services to ALS to aid in their day-to-day operations. These operations include staffing food management teams to assist in the development of health meals and culinary skills. FISCs provide the experts on the Navy Cash system-a system designed to reduce the overall amount of cash carried on ALS through the use of a cashless system for purchases made onboard ALS. FISCs provide Ship Store support, barber training, and retail management utilizing the Fleet Assistance Team. FISCs also provide ALS shore-based logistics liaison teams to assist with logistic situations, expedite requisitions, schedule stevedores, and act as a go-between when dealing with service suppliers (NAVSUP, 2010). A breakdown of FISCs by the geographical responsibility is shown in Figure 1. 


\section{e. Defense Logistics Agency (DLA)}

DLA evolved from the Defense Supply Agency, which started as a result of a presidential commission to determine the best approach to deal with the large buildup of military parts after World War II. The Defense Supply Agency was established in 1961 as an organization that maintained centralized management of common supplies based on the recommendation of the commission. After several revisions, DLA was officially adopted in 1977 (History of Defense Logistics Agency, 2011). The headquarters for DLA, at Fort Belvoir, Virginia, is the home of the Commander, Defense Logistics Agency whose role is comparable to the role Commander, Naval Supply Systems Command as related to the ALS (NAVSUP P-485, 2005, p. 1072.3).

\begin{tabular}{|l|l|}
\hline FISC & Geographic Area of Responsibility \\
\hline FISC Norfolk & $\begin{array}{l}\text { All CONUS east of the Mississippi River not otherwise } \\
\text { assigned; Europe and Middle East/Southwest Asia } \\
\text { requirements with U.S. vendors. }\end{array}$ \\
\hline FISC San Diego & $\begin{array}{l}\text { All CONUS west of the Mississippi River not otherwise } \\
\text { assigned. }\end{array}$ \\
\hline $\begin{array}{l}\text { FISC } \\
\text { Jacksonville }\end{array}$ & $\begin{array}{l}\text { North Carolina, South Carolina, Georgia, Florida, } \\
\text { Kentucky, Louisiana, Tennessee, Alabama, Mississippi, } \\
\text { Texas, Caribbean. }\end{array}$ \\
\hline $\begin{array}{l}\text { FISC } \\
\text { Puget Sound }\end{array}$ & $\begin{array}{l}\text { Washington, Oregon, Idaho, Alaska, Guam, Japan and } \\
\text { Western Pacific requirements with U.S. vendors. }\end{array}$ \\
\hline $\begin{array}{l}\text { FISC } \\
\text { Pearl Harbor }\end{array}$ & Hawaii \\
\hline FISC Yokosuka & Japan, Korea \\
\hline
\end{tabular}

Figure 1. Geographical Responsibility of FISCs (From NAVSUP P-486, 2005, p. 3005)

DLA is a supply support organization with administrative responsibility and control of items that are universal across all military services (NAVSUP P-485, 2005, p. 1072.3). DLA services provide over 84 percent of the spare parts utilized by all 
services. Additionally, almost 100 percent of the consumable items (food, clothing, medical supplies, etc.) are provided by the DLA services (DLA, 2011).

DLA comprises five main Defense Supply Centers (DSCs) and has a similar role in the Defense Supply System as the NAVICP has for the Navy Supply System (NAVSUP P-485, 2005, p. 1072.3). Each DSC has a responsibility for different material. These can be broken down as follows (Reese, B., 2010):

- DLA Troop Support, Philadelphia, Pennsylvania - lead center for food items, medical supplies, clothing, and industrial type items (e.g., bearings, wire rope, and sheet metal)

- DLA Energy, Washington, DC - lead center for bulk petroleum and bulk petroleum based chemicals

- DLA Disposition Services, Battle Creek, Michigan - lead center for reuse, transfer, donation, sale or disposal of excess material

- DLA Aviation, Richmond, Virginia - lead center for aviation weapon systems and environmental logistics support and is the primary supply source for nearly 930,000 repair parts and operating items

- DLA Land and Maritime, Columbus Ohio - lead element for supplying and sustaining land and maritime weapon systems and helping the military services plan for future demand

DLA utilizes Defense Depots (DDs) for its material distribution requirements. These DDs are basically a storage point for DLA material. Each cognizant DSC is responsible for the issue of material from a particular DD based on requisitions received and processes. Requisitions are not sent directly to the DD for issues unless directed to do so by the cognizant DSC (NAVSUP P-485, 2005, p. 1072.3).

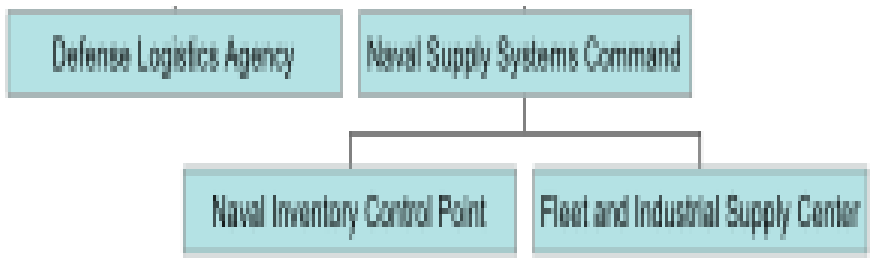

Figure 2. Hierarchy of Navy Supply System 


\section{How Material Arrives to Afloat Logistics Systems}

\section{a. Federal Catalog System}

To ensure proper requisitioning of specific items from the Department of Defense Supply System, a common language was developed. This common language included the naming, description, classification, and numbering of all items carried under centralized inventory control by the Department of Defense and the civil agencies of the Federal Government (NAVSUP P-485, 2005, p. 2030). DLA administers the Federal Catalog System following the direction of the Assistant Secretary of Defense.

Items that fall under the management of the Federal Catalog System are those that require central management. Therefore, items that will be procured and used locally are not included in this system. NAVSUP provides guidance for the introduction of items into the system, revisions to the systems and removal from the system (NAVSUP P-485, 2005, p. 2032).

\section{b. Federal Supply Classification System (FSC)}

The Federal Supply Classification (FSC) System's main purpose is to allow for the classification of all items in the supply system currently used by the Federal Government. Each item can be filed under only one four-digit class. The first two digits of the class designate the group or major category of commodities. The last two digits refer to the class or the subdivision within a group. The groups, which cover a broad range of categories, can be further broken down by classes-approximately 600 are in existence. Commodities, broken down by physical or performance characteristics, are allocated to each class. Taking the stock group and the class together determines the federal supply classification (FSC) (NAVSUP P-485, 2005, p. 2031).

\section{c. Cognizance Symbols}

These two-digit numeric-alpha codes are used to identify a stock numbered item with the Navy inventory manager of the specific category of material that the item falls under. The code also identifies which account holds fiscal responsibility 
for procurement of the item. While the cognizance symbol is an important aspect of the item identification, it is not an integral part of the stock number (NAVSUP P-485, 2005, p. 2001).

As an example, DLA items can quickly be identified because the number three or nine always precedes the cognizance symbol, except for cognizance symbol $3 \mathrm{H}$ material, which is managed by NAVICP MECH and 9Q material, which is managed by the General Services Administration (GSA) (NAVSUP P-485, 2005, p. 1072.3).

\section{d. National Stock Number (NSN)}

In support of the common logistics language developed through the Federal Catalog Systems, NSNs provide a unique identifier to items ordered in the military supply system. During World War II, the same item would often be listed under several different names, preventing services to locate or share items of supply (DLIS, 2010). The NSN format is comprised of a unique thirteen-digit number assigned by the Defense Logistics Information Service in Battle Creek, Michigan.

The FSC is followed by a two-digit country of origin code. This code identifies what country originally request the item be given an NSN (00 and 01 represent the United States). The last seven digits are sequentially assigned and are unique to each individual NSN (DLIS, 2010). The NSN is generated in response to a nonstocked item's repetitive ordering.

\section{e. Federal Logistics Data (FEDLOG)}

FEDLOG is an interactive query system that contains all of the basic management data necessary to prepare requisitions. It also contains an integrated historical record of deleted and superseded NSNs and the specific codes that show what action was taken on the particular item. This system also includes, among other pertinent information, units of issue, unit prices, shelf life codes and classification codes (i.e., confidential, secret, top secret, nuclear). FEDLOG does not contain Consolidated Afloat Requisitioning Guide Overseas (CARGO) items, Ships Store items, publications nor some types of special weapons (NAVSUP P-485, 2005, p. 2070). 


\section{f. $\quad$ Allowance Lists}

When an ALS is initially designed and built, it is given an allowance list by the fitting out activity that itemizes and quantifies the initial material requirements. They are used by the NAVICP to prepare the initial stock, custody, and/or locator records that the ship will require for proper inventory management of its authorized supply support materials. Once the fitting out activity completes its initial delivery of authorized material, the prospective supply officer will ensure all documentation and stowage requirements are met prior to final acceptance (NAVSUP P-485, 2005, p. 2089).

\section{g. Coordinated Shipboard Allowance Lists (COSALS)}

The COSAL provides both technical and supply information and provides the ship with basic guidance for determining the items and quantity of each item, which should be stocked by the supply department or held in the custody of other department heads. The COSAL is divided into three main sections with a short introductory section preceding the main body. Those three sections are Summary of Allowance Parts/Equipage/Components Lists (SOAPL); Allowance Parts Lists (APL)s and Allowance Equipage Lists (AELs); and the Storeroom Items (SRI)/Integrated Stock List (ISL) (NAVSUP P-485, 2005, pp. 2090-2094).

The SOAPL is a numerical sequence listing, by identification number, of all APLs and AELs that apply to a ship. It is broken down into four sections: A NAVICP Philadelphia managed, E - Electronic, H - Hull, Mechanical and Electrical (HME), and Z - Ordnance (NAVSUP P-485, 2005, p. 2092).

APLs are technical documents prepared for individual equipment/components that are on board (NAVSUP P-485, 2005, p. 2093). These items are authorized to be purchased using Equipment Maintenance Related Material (EMRM) funds. One analogy to describe what is an APL item is to take the ship and turn it upside down. If the equipment/components do not fall to the bottom of the upturned ship, it is an APL item and is authorized to be purchased with EMRM funds. Of course, this is only a guideline. AELs are technical documents prepared for various categories of 
equipage for mechanical, electrical, electronic and ordnance systems (NAVSUP P-485, 2005, p. 2093). These items are authorized to be purchased with Operating Target (OPTAR) or consumable funds.

Storeroom Items are authorized consumable items to be held in the ALS stock system to support equipment repairs. Once an ALS has undergone and Integrated Logistics Overhaul, the Storeroom Item is replaced with the Integrated Stock List. The basic difference between SRI and ISL is the incorporation of allowance changes related to configuration changes and changes justified by individual ALS demand history (NAVSUP P-485, 2005, p. 2094).

\section{h. Requirements Identified}

When a requirement is identified on a ship, the division responsible for repairs will enter a job into the Organizational Maintenance Management System-Next Generation (OMMS-NG). OMMS-NG allows the user to order repair parts against the open job. These requirements will be sent to the Relational Supply (RSUPPLY) system monitored by the Supply Department personnel. Once the responsible Department Head approves the parts in OMMS-NG, the Supply Department personnel will process the requisition. If the parts are available onboard, they will be pulled and issued to the requisitioner. If the parts are Not Carried Onboard (NC) or Not in Stock (NIS) the requisition will be forward to the cognizant FISC for fulfillment. If the FISC does not carry the part or it is out of stock on the part, the requisition will be forwarded onto the appropriate Navy or DLA ICP for fulfillment.

\section{B. SUPPLY CHAIN MANAGEMENT (SCM)}

\section{Basics of SCM}

Supply Chain management in layman's terms is the interconnectivity of multiple supply chains to meet an industry's needs. These are the company and business activities necessary to design, make, deliver, and use products or services (Hugos, 2002). A prime example of how the players interact is visible in Figure 3. The military can further tailor 
this description to state it is the activities necessary to provide food, parts, shelter, ammunition and fuel to forces throughout the world.

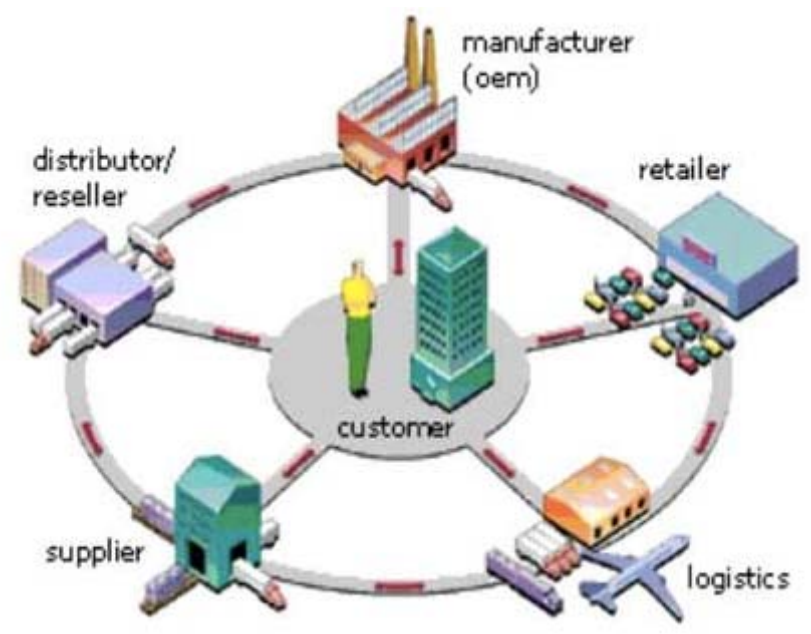

Figure 3. Key Players in Supply Chains (From DeAngelis, 2011)

Supply Chain Management is based on two fundamental blocks: that practically every product going to a customer encompasses the combined effort of several organizations, or supply chains, and that most organizations are only aware of operations within their domain, with few understanding the entire series of events necessary to deliver products to the final customer (North Carolina Supply Cooperative home page, 2011). Here is a further exploration into the definitions of a supply chain:

- Lambert, Stock and Ellram (1998) define a supply chain as the alignment of firms that bring products or services to market.

- Chopra and Meindl (2001) define a supply chain as consisting of all stages involved, directly or indirectly, in fulfilling a customer request. The supply chain not only includes the manufacturer and suppliers, but also transporters, warehouses, retailers, and customers themselves.

- Ganeshan and Harrison (1995) of Penn State University define a supply chain as a network of facilities and distribution options that performs the functions of procurement of materials, transformation of these materials into intermediate and finished products, and the distribution of these finished products to customers. These definitions all broach the subject of firms working together to provide a service to the customer. However, they do not address the needs within the supply chain itself. To address these, we must understand the definition of supply chain management. 
To begin understanding supply chain management, let us again look at a few definitions.

- Supply chain management is the systemic, strategic coordination of the traditional business functions and the tactics across these business functions within a particular company and across businesses within the supply chain, for the purposes of improving the long-term performance of the individual companies and the supply chain as a whole (Mentzer et al., 2001).

- Supply chain strategies require a total systems view of the linkages in the chain that work together efficiently to create customer satisfaction at the end point of delivery to the consumer. As a consequence costs must be lowered throughout the chain by driving out unnecessary costs and focusing attention on adding value. Throughput efficiency must be increased, bottlenecks removed and performance measurement must focus on total systems efficiency and equitable reward distribution to those in the supply chain adding value. The supply chain system must be responsive to customer requirements (Hines, 2004).

- From the Council of Supply Chain Management Professional's website, Supply Chain Management, as defined by the Council of Supply Chain Management Professionals (CSCMP), encompasses the planning and management of all activities involved in sourcing and procurement, conversion, and all logistics management activities. Importantly, it also includes coordination and collaboration with channel partners, which can be suppliers, intermediaries, third-party service providers, and customers. In essence, supply chain management integrates supply and demand management within and across companies.

These definitions paint a very clear picture of the supply chain management that operates not only up and down the supply chain, but across horizontal lanes to deliver their final products to their customers. If the managers neglect to ensure all areas of the supply chain have been cohesively linked together, the chances of success are significantly reduced. A supply chain must be able to change its partners easily to gain a competitive advantage. It must be an effective and efficient network for satisfying customer needs at appropriate prices and with a variety of goods and services at a given level of cost, agility, and risk (Higuchi \& Troutt, 2008). The basis of the Department of Defense's supply chain management policy is to plan for and resource all elements of the supply chain to meet customer demand by developing and establishing support strategies 
that effectively and efficiently provide supply chain resources to meet supply chain requirements for future time periods (DOD 4140.1-R, 2003, C2.1.1.1).

\section{Supply Chain Elements}

With the basics of supply chain management thoroughly explored, it is important to delve deeper into the subject and break the concept into five main elements. Supply chains have many moving parts that must be carefully coordinated in order to improve operations through process re-engineering, inventory reduction, improved demand tracking and more efficient transportation, to name only a few. In order to develop the most effective supply chain, one must look at the six main elements of the supply chain: production, supply, inventory, location, transportation, and information. Figure 4 shows how these individual elements interact in their system. In Figure 5, the individual element's responsiveness and efficiencies are shown.

\section{a. Production}

Production refers to the capacity of a supply chain to make and store products utilizing factories and warehouses. Decision managers are faced with some fundamental questions in the production decision-making process. These questions include: What products do consumers desire, how much are they willing to buy, and how do decision makers resolve the trade-off between responsiveness and efficiency (Ligus, 2010)?

Factories are generally built to accommodate one of two approaches: product and functional (Hugos, 2002). A factory that is product-focused performs different operations to fabricate a product from producing individual parts to assembly. This tends to develop expertise in a set of products versus a function. A factory that is functionally focused performs more specialized functions, such as only fabricating parts or only assembling parts. This approach develops expertise in a functional area vice in a product set (Hugos, 2002).

As with factories, warehouses are also built to fulfill a particular approach. The three main approaches are stock keeping, job lot, and crossdocking (Hugos, 2002). 
Stock keeping unit (SKU) storage allows all types of one product to be stored in a centralized area. Job lot storage allows all products associated with a particular customer or job to be stored together. This approach is efficient for a picking and packing operation, but often is more space intensive than the SKU storage approach. The last approach is utilized by Walmart to increase supply chain efficiency. The facility is used as a staging zone between large quantity deliveries and those smaller lot deliveries destined for individual stores. The smaller lots are bundled with the daily delivery requirements and quickly loaded onto the outbound trucks (Hugos, 2002).

\section{b. Inventory}

The decision of how much inventory is stocked at each stage must achieve a balance between having too much and not enough to meet demand. Inventory in this situation can be raw materials, work in progress, to finished goods held by retailers. The main purpose for inventory is to act a buffer against the lags of a supply chain (Hugos, 2002). Inventory decisions depend on maintaining the right levels of stock and the control policies put into force to manage those levels. The satisfaction of any organization's customer and the success of the organization's day-to-day operations depend on these inventory levels (Ligus, 2010).

Managers must determine whether responsiveness or efficiency is their priority in order to be successful in the inventory decision process. If responsiveness is the goal of the organization, then larger amounts of inventory are imperative. However, if the organization's focus is efficiency, the levels of inventory must be closely guarded. Too much inventory on-hand at any one particular time will adversely affect efficiency. There are three basic types of inventories that determine the overall inventory levels of any organization: cycle, safety, and seasonal inventory.

Cycle Inventory is the amount necessary to maintain demand between purchases. Because of the concept of economies of scale (cost of producing an additional unit of a product decreases as the volume of output increases), organizations often purchase large orders. Yet, they will be sacrificing some efficiency due to the increased holding costs. 
Safety Inventory is held only as a buffer to mitigate unforeseen demand or manufacturing fluctuations. The important question for this type of inventory is how much would be lost in sales due to insufficient inventory.

The last type of inventory, seasonal, is held in anticipation of increases due to certain times of the year or certain known events (think hurricane season, a snow storm or a mass deployment of forces) (Hugos, 2002).

\section{c. Location}

Ensuring production plants, distribution and stocking facilities are located in the areas best suited to meet the customer's needs is essential (Ligus, 2010). When determining best locations, several factors must be considered: weight and dimensions of the products to be shipped, cost of labor, taxes and tariffs required, proximity to suppliers, as well as issues dealing with interstate and worldwide distribution (Hugos, 2002).

Location refers to the geographical area of the facilities to be used in a supply chain, as well as the determination of which activities shall be accomplished at those facilities. The organization's primary goal (responsiveness or efficiency) will be crucial in determining whether activities are centralized to achieve economies of scale or decentralized to be closer to customers and reduce their wait time. Due to the large sum of money required and the long-term nature of locations, decisions become very strategic and require serious research and analysis (Hugos, 2002). These decisions affect the entire supply chain process through increased costs, delivery time, processing times and policy issues.

\section{d. Transportation}

Transportation refers to the movement of all materials necessary between each facility in a supply chain. Having a solid transportation system in place is essential to customer satisfaction, a smooth supply chain management, as well as a lasting impact on amount of required inventory. The recurring theme of overarching goals is especially pertinent when dealing with transportation. If items are shipped via air, inventories can 
be significantly reduced and the responsiveness is greatly increased. However, the increased cost in transportation negates the savings from the lower inventory levels. The industry standard for transportation costs is 30 percent of the product cost (Ligus, 2010). Slower modes of transportation improve efficiency due to lower costs, but the slow times of rail or ship transport significantly reduce the overall responsiveness of the supply chain system.

There are six main modes of transport: ship, rail, pipelines, trucks, air, and electronics. Let us look at each very briefly and determine their affect on efficiency. Ship is slowest, but it is most cost efficient. Rail is slow and restricted to those areas serviced by rail lines, but it is very cost efficient. Pipelines are restricted to the product that can be sent and are expensive in the initial development, but are also cost effective if they are already in existence. Air is the most expensive and therefore not as efficient, but it is an extremely fast mode. And the last transport, electronic, is the fastest mode and exceedingly flexible and efficient, but it is seriously limited in the product it is capable of transporting (Hugos, 2002).

\section{e. Information}

Albert Einstein once said, "Know where to find the information and how to use it-That's the secret of success." This is extremely evident in the development and operations of supply chains. Deciding what information must be collected, which information should be shared, what the acceptable parameters for timeliness are, and what the consequences for inaccuracy are, is the nervous system of any supply chain. This is the basis that affects all four other drivers of supply chains. By ensuring strong information is available for immediate use, organizations are able to make sound decisions regarding the flow of the supply chain to maximize profits.

There are two main uses for information: coordinating daily activities and forecasting and planning. Coordinating daily activities deals with the other four drivers. How much use of information systems is paramount to the continued success a chain will enjoy from the sharing of information (Ligus, 2010). Coordinating daily activities is related to the functioning of the other four supply chain drivers (production, inventory, 
location, and transportation). The companies in a supply chain use the information on the individual product's supply and demand to decide on inventory levels, production amounts, transportation modes and the locations to house the product. Forecasting and planning is used to anticipate and meet future demands (Hugos, 2002).

Based on past information gathered and industry information, modern-day supply chains anticipate the amount necessary to meet demand. This system provides a more analytical approach than the "gut feeling" or "in my experience" approaches from the past. Responsiveness and efficiency are achieved by evaluating the benefits good information can provide in opposition to the cost of acquiring that information. While gathering and storing this information can significantly enhance the performance of an organization, care must be taken to ensure the cost does not outweigh the benefits received. How much return on your investment will you achieve from the acquisition of the information? Now, compare that to the cost of developing a system to gather the information and store the information, the cost to analyze the data and the cost to train management to use the analyzed data.

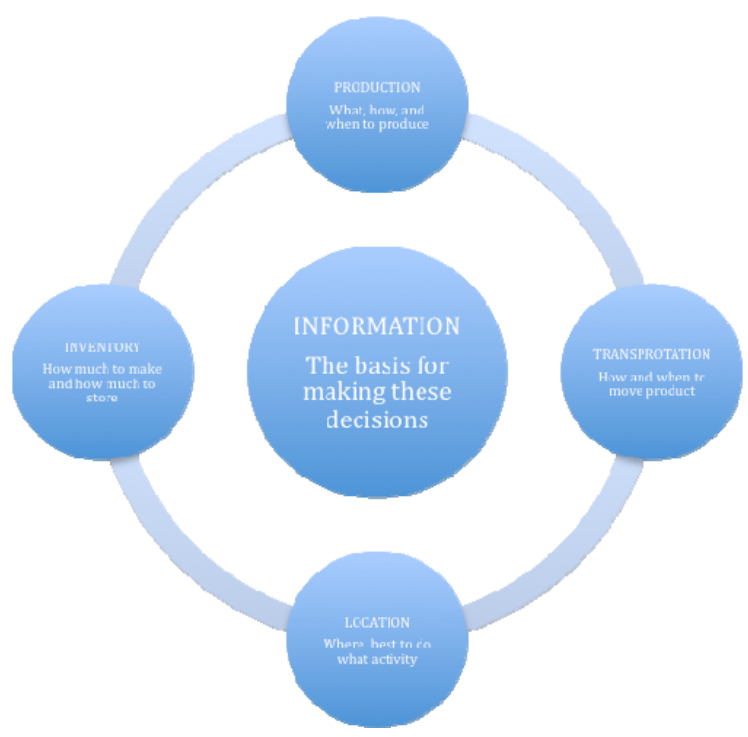

Figure 4. Responsiveness Versus Efficiency (From Hugos, 2002) 


\section{Aligning the Supply Chain}

There are three steps to aligning a supply chain with a particular business strategy: understand the markets the organization serves, define the strengths or core competencies of the organization, and develop the supply chain capabilities necessary to support the roles of the organization (Hugos, 2002). When understanding the markets, it is important to think of the needs of the customer. In supply chain management, it is imperative to see past the horizon towards the long view. By answering questions such as what kind of customers are served by the organization and what customers are served by the organization's customer, organizations can determine their supply chain needs and focus (responsiveness or efficiency).

To define core competencies, organizations must understand the role they play in their supply chain — both close and long range. The organization must understand its core competencies as it pertains to its own operations. The answers to these questions decide the roles that best fit an organization in a supply chain. Developing the needed supply chain capabilities is the last step in aligning a supply chain to an organization's business strategy. Once the markets and the roles of an organization have been identified, each driver can be developed and administered with either responsiveness or efficiency dominating (Hugos, 2002).

\begin{tabular}{|c|c|c|}
\hline Driver & Responsiveness & Efficiency \\
\hline Production & $\begin{array}{ll}- & \text { Excess Capacity } \\
- & \text { Flexible manufacturing } \\
\text { - } & \text { Many small factories } \\
\end{array}$ & $\begin{array}{ll}- & \text { Little excess capacity } \\
\text { - } & \text { Narrow focus } \\
\text { - } & \text { Few central plants } \\
\end{array}$ \\
\hline Inventory & $\begin{array}{ll}\text { - } & \text { High inventory levels } \\
\text { - } & \text { Wide range of items } \\
\end{array}$ & $\begin{array}{ll}\text { - } & \text { Low inventory levels } \\
\text { - } & \text { Fewer items } \\
\end{array}$ \\
\hline Location & $\begin{array}{l}\text { - } \quad \begin{array}{l}\text { Many locations close to } \\
\text { customers }\end{array} \\
\end{array}$ & $\begin{array}{ll}- & \text { Few central locations serve } \\
\text { wide areas }\end{array}$ \\
\hline Transportation & $\begin{array}{ll}\text { - } & \text { Frequent shipments } \\
\text { - } & \text { Fast and flexible mode }\end{array}$ & $\begin{array}{ll}\text { - } & \text { Shipments few and large } \\
\text { - } & \text { Slow, cheaper modes }\end{array}$ \\
\hline Information & $\begin{array}{l}\text { - Collect and share timely, } \\
\text { accurate data }\end{array}$ & $\begin{array}{l}\text { - } \quad \text { Cost of information drops } \\
\text { while other costs rise }\end{array}$ \\
\hline
\end{tabular}

Figure 5. Supply Chain Capabilities (From Hugos, 2002) 


\section{Bullwhip Effect}

The "bullwhip effect," so named by Proctor \& Gamble whilst studying the demand for diapers, is a phenomenon that refers to unanticipated fluctuations in the supply chain process (Federal Reserve Bank of Dallas, 2011). It refers to the tendency of the variability of order rates to increase as they pass through the echelons of a supply chain towards producers and raw material suppliers. The basis of this phenomenon is that each player in the supply chain system (customer, supplier, wholesaler, manufacturer) orders what they "believe" to be the demand of their product independent of the other players. The exaggerated negative effects within the supply chain cause major order swings throughout the chain (Disney, 2009). See Figure 6 for a chart representation of these fluctuations.

Distorted information, or the lack of information, is the main cause of the 'bullwhip effect,' named after the way the amplitude of a whip increases down its length. In essence, the bullwhip effect states that fluctuations in orders become larger at every step up the supply chain, from the customer through to the raw materials suppliers. (Federal Reserve Bank of Dallas, 2011)

To minimize this information distortion, information sharing must be well established and deliver better predictions of demand. Reduction in delay time throughout the supply chain is another method to help eliminate the bullwhip effect. This has been proven via the Beer Game, a simulation game that was developed by professors at MIT Sloan School of Management in the 1960s. The purpose of the game is to meet the demand for beer by customers through a multistage supply chain with as little back orders and inventory as possible. The game conveys the frustrations and erratic behavior of supply chains that do not share key demand data (Beer Distribution Game, 2011).

Boom and bust is an extreme case of the bullwhip effect that occurs when life cycle becomes very short. The demand for a product grows too rapidly, causing inventories to be depleted. In response to the shortages, consumers will go to several locations to order, inflating the actual demand. Once the system catches up to inflated demand, the manufacturers are left with huge inventories and excess capacity (Higuchi \& Troutt, 2008). 
The solution to the boom and bust includes open lines of communications throughout the supply chain. When the correct information is transmitted to all those involved in the system, erroneous demands are eliminated. Organizations can adjust their demand via the media in which they deliver their adverts. Take the example of the Nintendo Wii during the 2006 Christmas season. Nintendo's advertisements were extensive to the point the company could not meet the demand. The demand was well over the supply into the later months of 2008 (Reisinger, 2009).

\section{The Bullwhip Effect in Action}

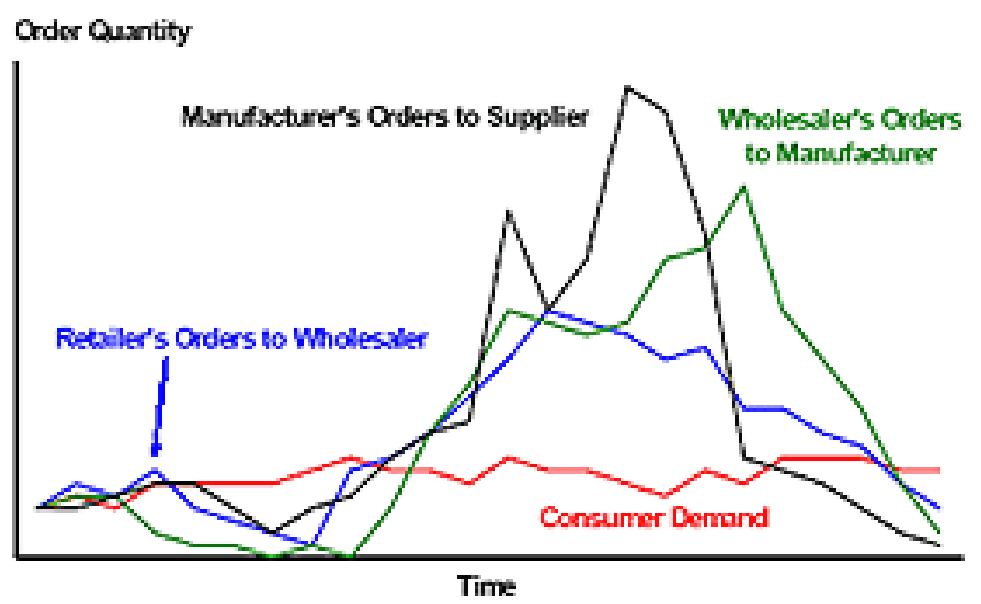

Figure 6. Bullwhip Effect on Supply Chain (From Federal Reserve Bank of Dallas, 2011)

\section{LITERATURE REVIEW}

\section{Introduction}

There are several examples in the commercial world where supply chain management and forecasting models have been utilized to reduce and/or eliminate excess material. The complex algorithms used have allowed airline, hospital and electronic companies to streamline their requisitioning processes to be Lean entities that employ Just-in-Time and Vendor Push systems to reduce their inventories and increase their bottom line. 
Just-in-Time inventory system (JIT), or the Toyota Production System, refers to a supply system where no excess material is kept in stock. Only the number of parts necessary to complete a particular job or fill a particular order are procured. There are no facilities available for storing stock and therefore costs are significantly reduced. More precisely, it is making only "what is needed, when it is needed, and in the amount needed" (Toyota Production System, n.d.). This will produce a quality product efficiently through the elimination of waste, inconsistencies, and unreasonable requirements on the production line (Toyota Production System, n.d.). See Figure 7 for the pros and cons of utilizing just-in-time inventory systems.

\begin{tabular}{|l|l|}
\hline \multicolumn{1}{|c|}{ PROS OF JIT } & \multicolumn{1}{c|}{ CONS OF JIT } \\
\hline Simplified inventory flow & $\begin{array}{l}\text { Interruptions in supply flow is the biggest concern, } \\
\text { especially during the initial phase as well as during } \\
\text { periods that bring up business continuity issues } \\
\text { (natural calamities, political unrest, etc.) }\end{array}$ \\
\hline Setup time is considerably reduced & $\begin{array}{l}\text { If not followed exactly the way it is theorized, } \\
\text { which may be impractical at times, following JIT } \\
\text { would do more harm than good, as even the } \\
\text { slightest gap in precision and coordination can } \\
\text { expose the manufacturer to losses, both in terms of } \\
\text { capital and time }\end{array}$ \\
\hline $\begin{array}{l}\text { Optimum synchronization of production scheduling, } \\
\text { work hour consistency and demand }\end{array}$ & $\begin{array}{l}\text { If the part of the supplies are not in good condition, } \\
\text { the production would have to wait for fresh } \\
\text { supplies, as there is no backup inventory. This may } \\
\text { cause a lot of loss of time. }\end{array}$ \\
\hline $\begin{array}{l}\text { No storage required, as supplies happen throughout } \\
\text { the day, and when needed }\end{array}$ & $\begin{array}{l}\text { A fault in inventory forecasting methods can land } \\
\text { the manufacturer in huge financial losses. }\end{array}$ \\
\hline $\begin{array}{l}\text { Improved manufacturing process due to the } \\
\text { unavailability of inventory backup in case of } \\
\text { production goof ups }\end{array}$ & $\begin{array}{l}\text { Also, the advantage of stocking inventory when } \\
\text { prices go down is also lost, as JIT means getting } \\
\text { supplies for the present market value. }\end{array}$ \\
\hline
\end{tabular}

Figure 7. Pros and Cons of Just-in-Time Inventory (From Shukla, 2010)

A perfect example of this in a working situation comes from the Toyota website. Its example involves building automobiles but could easily be adapted for any commodity.

In order to deliver a vehicle ordered by a customer as quickly as possible, the vehicle is efficiently built within the shortest possible period of time by adhering to the following:

-When a vehicle order is received, a production instruction must be issued to the beginning of the vehicle production line as soon as possible. 
-The assembly line must be stocked with required number of all needed parts so that any type of ordered vehicle can be assembled.

-The assembly line must replace the parts used by retrieving the same number of parts from the parts-producing process (the preceding process).

-The preceding process must be stocked with small numbers of all types of parts and produce only the numbers of parts that were retrieved by an operator from the next process. (Toyota Production System, n.d.)

Vendor Push or vendor-managed inventory (VMI) systems operate under the concept that the supplier and customer have a data-sharing relationship where both benefit. A customer gives the supplier full access to inventory levels and sales levels, and the supplier will meet agreed-upon objectives. VMI is often paired with consignment, which allows the customer to only purchase the merchandise when merchandise is actually sold (Evanko, 2010). In VMI, the supplier is responsible for monitoring demand for items in their purview and generating the orders to ensure that demand is met. Another aspect of VMI is the ability to improve the financial position of a company. Because the inventory is on the supplier's books and not on the customer's, the customer can realize a more profitable situation. The customer is not responsible for merchandise that does not sell or is damaged before purchase.

Suppliers get the comfort and security of a continued relationship with their customer. This allows them to develop a more constant inventory level on their side. In addition, suppliers are privy to a steady and reliable flow of income. As long as the supplier can continue to meet the objectives agreed upon with the customer, the supplier is almost certainly guaranteed a long relationship, as the cost for the customer to switch would be too high (Frahm, 2003). Figure 8 outlines the advantages and disadvantages of utilizing vendor-managed inventory.

\section{Dell}

When thinking about computers and their volatility, a quote by former Dell CEO Kevin Rollins sums up the situation:

The longer you keep it the faster it deteriorates - you can literally see the stuff rot. Because of their short product lifecycles, computer components 
depreciate anywhere from a half to a full point a week. Cutting inventory is not just a nice thing to do. It's a financial imperative. (Atkinson, 2005)

When considering the short shelf of these systems, it is no wonder why Dell was quick to make the transition to the JIT inventory system. Dell procures no parts until an order is placed. Because it has built a business around cutting out the middleman, it is able to deal directly with companies, such as Intel, which creates the parts necessary for the units and removes itself from the actions of research and development (Magretta, 1998). This is the basis of a direct model where Dell sells directly to the customer. In an interview with former CEO Michael Dell, he stated some of the most important benefits of utilizing the JIT system in addition to those already addressed is the ability to respond to the rapid changes in computer technology (Magretta, 1998). The example used was if Dell carries 11 days of inventory and the competition carries 80 days of inventory, Dell can start implementing the new technology 69 days before the competition (Magretta, 1998). 


\begin{tabular}{|l|l|}
\hline \multicolumn{1}{|c|}{ PROS OF VMI } & \multicolumn{1}{|c|}{ CONS OF VMI } \\
\hline $\begin{array}{l}\text { Fosters cooperation in the supply chain-- } \\
\text { forms partnerships and cross-functional } \\
\text { lines of communication that can help to } \\
\text { improve the pipeline process and } \\
\text { relationships }\end{array}$ & $\begin{array}{l}\text { Vendor's administrative costs increase- } \\
\text { vendor's responsibilities increase and more } \\
\text { work needs to be done }\end{array}$ \\
\hline $\begin{array}{l}\text { Fast way to improve results-can be } \\
\text { implemented in a short amount of time and } \\
\text { provide considerable benefits over existing } \\
\text { performance }\end{array}$ & $\begin{array}{l}\text { Hard to use with volume discounts and } \\
\text { special pricing-alternate pricing strategies } \\
\text { will have to be worked out to the } \\
\text { agreement of both parties }\end{array}$ \\
\hline $\begin{array}{l}\text { Maximizes in-stock position-can increase } \\
\text { customer service levels and reduce stock- } \\
\text { outs through better understanding of } \\
\text { demand and more sophisticated inventory } \\
\text { policies }\end{array}$ & $\begin{array}{l}\text { Complicates the system in the short run- } \\
\text { new systems can start immediately but } \\
\text { roles of employee, vendor and customer } \\
\text { may not be clear at first }\end{array}$ \\
\hline $\begin{array}{l}\text { Reduces overall supply chain costs a fresh } \\
\text { look at supply chain processes will identify } \\
\text { shortcomings and better information helps } \\
\text { smooth demand and reduce inventory }\end{array}$ & $\begin{array}{l}\text { Retailer risks loss of control/flexibility- } \\
\text { especially when procedures are new; } \\
\text { understanding and ability to control } \\
\text { procedures is low }\end{array}$ \\
\hline $\begin{array}{l}\text { Sales are higher for vendor and customer- } \\
\text { increased service levels will maximize in- } \\
\text { stock positions and notch up sales levels }\end{array}$ & $\begin{array}{l}\text { Manufacturer takes one-time volume } \\
\text { reduction-inventory is withdrawn from } \\
\text { the supply chain, which reduces production } \\
\text { requirements }\end{array}$ \\
\hline $\begin{array}{l}\text { Minimal benefits for manufacturer until } \\
\text { critical mass-manufacturers do not } \\
\text { integrate DRP into MPS or MRP until 50\% } \\
\text { of overall sales volume is through VMI }\end{array}$ \\
\hline
\end{tabular}

Figure 8. $\quad$ Pros and Cons of Vendor Managed Inventory (From Evanko, 2010)

Dell's supply chain consists of the customer, Dell's website, its assembly plant, its suppliers, and the supplier's suppliers (Iba, 2009). This organization allows Dell to respond to quantity demands, provide short lead times (often seven days or less), continue to provide the most current innovation on the market, provide an inordinate amount of customizable products, and respond quickly to fluctuations in supply requirements (Iba, 2009). The main drivers of this system are low facility costs, low inventory costs, high information costs, and high transportation costs due to the constant 
small orders versus few large orders (Iba, 2009). The trade-off to the higher costs from smaller supply orders is higher customer satisfaction. Figure 9 represents Dell's direct model.

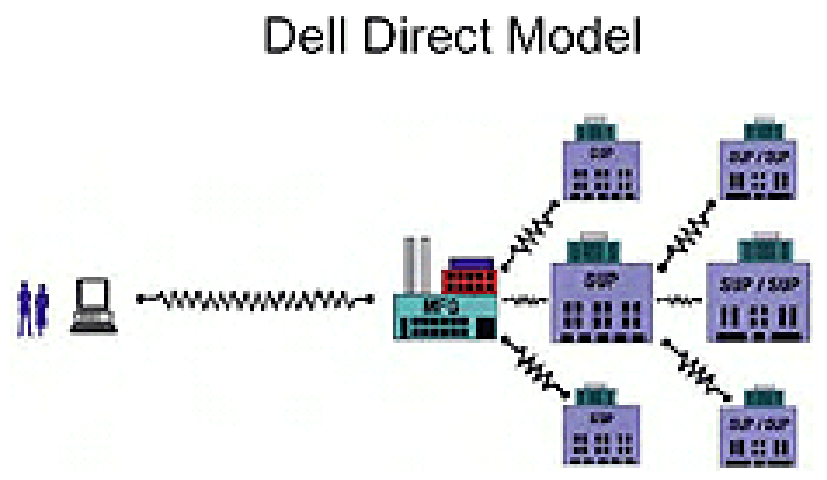

Figure 9. Dell’s Direct Model (From Federal Reserve Bank of Dallas, 2011)

\section{Walmart}

Along the same lines as Dell, Walmart utilizes a system known as vendormanaged inventory (VMI), a supply-chain initiative where the supplier is authorized to manage inventories of stock-keeping units at various locations (Cetinkaya \& Lee, 2000). This allows the distortion of demand information (known as the bullwhip effect) transferred from the retailer to the supplier to be minimized, stockout situations are reduced, and inventory-carrying costs are reduced (Cetinkaya \& Lee, 2000). Walmart is the model corporation for smart technology to ensure a lean culture. It grants its vendors access to its IT systems, allowing the use of bar codes to track demand and trends at each individual store. This ensures vendors are not stocking products that are not in demand at a particular location, while anticipating and reacting to trends in each individual market. Walmart's logistics system is represented in Figure 10. 


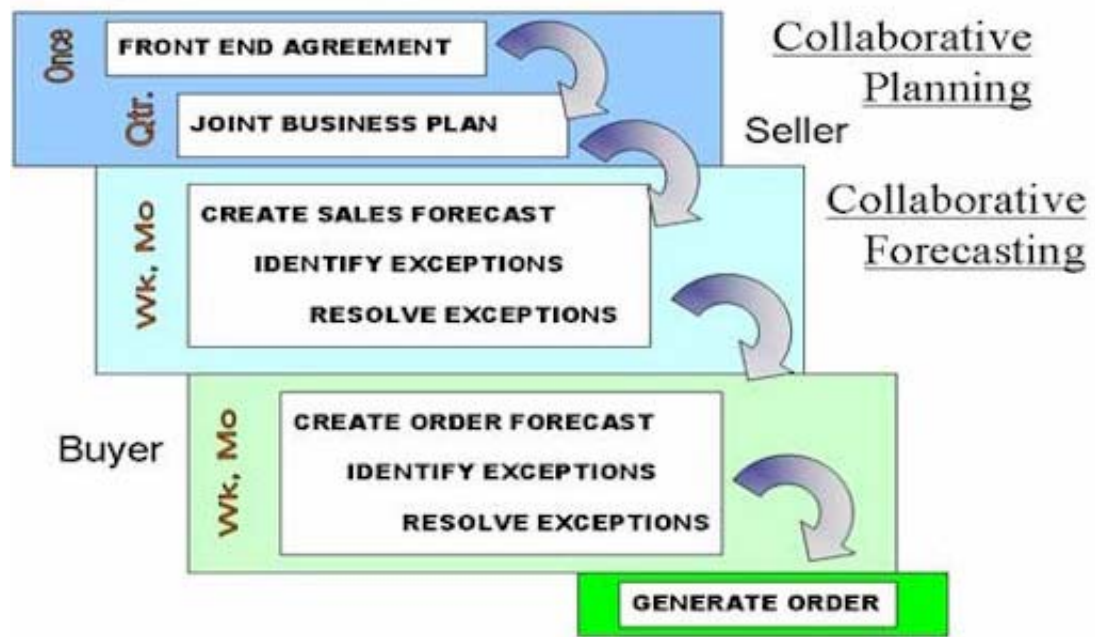

Figure 10. Walmart’s Logistics System (From Global Text Project, 2010) 
THIS PAGE INTENTIONALLY LEFT BLANK 


\section{EXCESS MATERIAL}

Excess material is the nemesis of an efficient supply chain. When the amount of excess material in an organization becomes too large, the organization will begin to lose its effectiveness, as large amounts of money can become entangled in the maze of unnecessary inventory. In 2009, the Panel on Defense Acquisition Reform reported the Navy had $\$ 7.5$ billion more of various parts than needed, which was 40 percent of its inventory (DOD Supply Chain Management, 2009).

This inventory is often caused as a result of the bullwhip effect in addition to changes in market demand and unforeseen market fluctuation. But in the Afloat Logistics System (ALS), there are four main factors that lead to excess material: allowance procedures, addition of equipment, removal of equipment, and unit of issue errors.

\section{A. HOW AFLOAT LOGISTICS SYSTEMS GENERATE EXCESS MATERIAL}

\section{Allowance Procedures}

All Afloat Logistics Systems (ALS) are outfitted with an initial allowance of parts to be held on board. These are listed on the Consolidated Shipboard Allowance Listing (COSAL) and are composed of Hull, Mechanical and Electrical (HME), Maintenance Assistance Modules (MAMs), and Operating Space Items (OSI) (NAVSUP P-485, 2005, p. 1526). Allowance can be modified by Demand Based Inventory (DBI). These are items on a ship that have generated a demand of more than two issues within a six-month period. The absence of demand can also affect allowance levels by designating an item excess due to lack of demand.

\section{Configuration Changes - Addition of Equipment}

All Afloat Logistics Systems are provided with an initial COSAL providing the basic guidance for determining the items (and quantity of each item) that should be stocked by the supply department or held in the custody of other department heads. It is 
essential that change be incorporated promptly upon receipt, and that corrective action be taken when it is determined that any part of the COSAL is inaccurate or incomplete (NAVSUP P-485, 2005, p. 2090).

The majority of these changes occur as a result of an overhaul or availability. Once the new equipment is installed, the alteration activity will determine if the current Allowance Parts Listing (APL) covers the equipment installed. If the current APL does not cover the new components, the alteration activity will produce an Allowance Appendix Page (AAP) that acts as official APLs until the COSAL is republished.

\section{Configuration Changes - Removal of Equipment}

When equipment is removed from an ALS during an overhaul or availability, the applicable APL must be deleted from the Summary of Effective APLs/AELs (SOEAPL) and any repair parts applying only to that APL must be transferred as excess and removed from stock records. If the repair parts apply to other APLs, only the APL that was removed from the ALS should be lined out (NAVSUP P-485, 2005, p. 2104).

If the equipment removed has been removed from the entire ALS system, the issue becomes how to reduce the inventory when no demand will ever be generated in the system. While there is no firm way to determine the amount of excess inventory in the ALS, over the past 20 years, one can assume there has been a significant amount of obsolete systems due to the exponential increases in technology and the improvements in weapon systems.

\section{Unit of Issue Errors}

One of the most easily avoided excess material situations that occurs is utilizing the improper unit of issue when ordering an inventory item. If attention is not shown when verifying orders placed against the most current FEDLOG, Supply Officers can see themselves receiving 100 cases of an item versus 100 individual items. This is a common but unnecessary cause of excess material. 


\section{B. ALS MANAGEMENT OF EXCESS MATERIAL}

\section{Relational Supply (RSUPPLY)}

RSUPPLY performs most of the clerical functions of supply to include identifying excess material. The system designates inventory items with reorder codes that determine whether an item is automatically ordered after issues. There are four main allowance type codes (AT Codes) assigned to inventory items on ALS. These are: ATC 1 assigned to COSAL supported items; ATC 4 assigned to non-COSAL supported items that have experienced a demand of two or more times within the past six months; ATC 6 assigned to excess material that has not experienced sufficient demand within designated timeframe and subject to offload; and ATC 8 assigned to items that have not experienced sufficient demand to keep as demand-based item.

The Supply Officer will review the ATC 4, 6, and 8 items to determine if they are legitimate codes for each particular part and whether retention or offloading is appropriate. If the Supply Officer concluded the items should be offloaded, the Material Turned into Store (MTIS) process is utilized.

\section{Material Turned Into Stores (MTIS)}

Ready for issue (RFI) excess material with an extended money value (EMV) of $\$ 50$ or more is processed through MTIS. This exists primarily to process unneeded (or excess to allowance/authorized demand based levels) RFI material turn-ins from customer activities and return them to stock to meet outstanding or future Navy requirements. When authorized by the Integrated Material Manager (IMM), credit may be given for end-use MTIS. Credit for Fleet turn-ins is given to the Type Commander (TYCOM) allotment indicated by the fund code on the expenditure/transfer document per the IMM's authorized stocking levels.

\section{Realtime Reutilization Asset Management (RRAM)}

The Naval Inventory Control Point (NAVICP) created the Realtime Reutilization Asset Management (RRAM) program to provide on-line, realtime, Total Asset Visibility (TAV) of residual/excess material and selected Sponsor Owned Material, to efficiently 
capture demand data for residual material currently residing in system-wide end-use inventories, and to increase asset visibility of material available to provide a mechanism for automated requisitioning of residual assets and to ensure proper replenishment decisions by offsetting potential buys (NAVSUP website, 2010).

RRAM material is centrally processed at the NAVICP-Mechanicsburg RRAM site. RRAM material will continue to be located in existing RRAM warehouses managed by the cognizant asset holders. For Issue Priority Groups (IPG) I, II and III requisitions with Service Codes of "N" "R" or "V" (less 207 and 224), and for all requisitions with fund codes associated with NAVSEA TOB, material will be issued from RRAM inventories first, prior to being filled by supply system stock. Part numbered items will be processed using the ANSRS (Automated Non-Standard Requisitioning System). ANSRS will equate the part number with a NSN/NICN. The NSN/NICN will then be receipted into the RRAM database (NAVSUP, 2010).

\section{WHAT IS BEING DONE TO REDUCE EXCESS MATERIAL}

\section{Current Excess Levels}

Due to rising costs and funding constraints, excess material has found itself on center stage as an avoidable cost of doing business. According to conversations with Mr. Steven Weir from Naval Supply Systems Command, Code 41, the ALS's 87 units currently contain 228,397 individual line items of excess material with an extended money value of approximately $\$ 238,209,973$. While the line items and dollar amounts are available, the Navy has no way, at this time, to determine what the actual line items are. This information is essential to determining the correct course of action by identifying if the excess material is associated with obsolete material, which must just be removed and discarded, or if the material can be used elsewhere in the ALS.

\section{Realtime Reutilization Asset Management (RRAM)}

As stated above, RRAM is NAVICP's current solution to the excess material problem. It was a commercial-off-the-shelf program implemented in 2003 that is intended to provide ALS access to the current levels of excess material available in the 
fleet. The ALS should check this database first as the items listed are sunk costs and therefore can be delivered to the ALS free of charge. Standard procedures onboard ALS is to confer with RRAM prior to releasing requisitions to determine if the item can be obtained for free. If there are no listings for the item in RRAM, the ALS will release the requisition to be filled by the supply system.

\section{WHAT IS THE PROBLEM WITH THE CURRENT SYSTEM?}

It is apparent with over 200,000 line items of excess material, that the current system is not as effective in dealing with excess material as hoped. There are many possible reasons for the ineffectiveness of the current system, namely parts from obsolete systems, lack of procedure compliance, poor system design, and lack of time to identify excess material onboard.

Parts that are on the ALS and are associated with obsolete systems will never generate any demand. For the RRAM system to be effective, the parts must have been turned into an MTIS facility, be on record for the ALS to search and be a part with demand. If the obsolete system's parts are in RRAM and no ALS has the system, there will be no one requesting these parts from RRAM. These obsolete parts will sit in the system indefinitely. In addition, if the ALS never removes the parts from their storerooms, the obsolete parts will never be put into the system and will continue to occupy valuable shelf-space.

In the RRAM procedures, the ALS is to enter all requested parts into RRAM prior to requisitioning from the main supply system to see if excess material exists. However, this is often not accomplished for several reasons. These include, but are not limited to, lack of manpower, lack of time, slow upload/download speeds and improper enforcement

of the procedures by upper management. It is often the case that the ALS will not be manned to capacity due to rule violations, family disaster, Individual Augmentee requirements, medical issues or lack of qualifications. These situations put a strain on the supply department because their manning is below the recommended amount. To compensate for the reduction in workforce, the supply personnel often forego completing the extra step to check RRAM when trying to fulfill requisitions. 
To be truly effective, RRAM must be integrated as part of the requisitioning process. There must be no way to bypass the step of checking for excess material in RRAM for fulfillment of the outstanding requirement. Because the system is not integrated into the entire business process, it is ineffective at reducing the excess material levels in the supply system.

As mentioned above, manning issues can cause steps to be skipped in order to conserve time. This issue can also prevent proper validation of the COSAL. Supply department organizations will be unable to properly review every stock record for proper excess material codes and will often forego removing the excess material, completing the transfer paperwork, schedule the appointment with MTIS, and prepare the items in the exact manner requested by the MTIS facility. More times than not, it is easier to just leave the excess material in the storerooms and allow the next group of individuals to deal with the issue. 


\section{PROPOSED SOLUTION}

In the Navy, there has been a long history of poor supply chain management. The focus often is on getting and keeping parts. With the long lead times and infrequent replenishment schedules of the past, the mentality to hoard parts is understandable. Even into late 2009, Defense Logistics Agency (DLA) had this to say about its procurement policies:

The Department struggles to implement sound contracting policies such as clearly defining requirements using appropriate contract type and exercising effective contract management. In absence of these, DOD exposes itself to unnecessary risk and may not be able to ensure that tax dollars are spent on goods and services that provide the best value. (DOD Supply Chain Management, 2009)

However, with increased communication capabilities, increased number of distribution centers (DLA operates 26 worldwide), improved transportation lines and sophisticated logistics software (Enterprise Resource Planning software) the need for large inventories is becoming obsolete. These old mentalities are attributing to the increased amount of excess material still being retained on Afloat Logistics Systems (ALS).

\section{A. PREVENTING MORE - USING CURRENT SYSTEM}

The Defense Acquisition Community has been working diligently to reduce the amount of excess material in the Department of Defense system. There have been several Congressional inquiries to determine the standing of the acquisition processes. The most recent instruction for the Operation of the Defense Acquisition System is Department of Defense Instruction 5000.2, which establishes the management framework that implements these policies and principles (Defense Acquisition Guidebook, n.d.).

The Packard Commission in 1986, the Goldwater-Nichols Act of 1986, the Acquisition Streamline Act of 1994, the Clinger-Cohen Act of 1996 and Intelligence Reform and Terrorism Prevention Act of 2004 prompted acquisition reform and transformation (Defense Acquisition Guidebook, n.d.). It is through these reformation 
attempts that the prevention of excess material at the organizational level will be achieved. On the ALS, tighter controls over the items being ordered and strict adherence to utilizing the Realtime Reutilization Asset Management (RRAM) system first when ordering parts to identify material already paid for will help to prevent more excess material being generated. In addition, when parts ordered for a job are not used nor needed for completion, they must be turned into Material Turned into Stores (MTIS) vice kept in inventory for future use.

If the current policy of checking RRAM prior to requisitioning was enforced, it could prove more effective than its current standing. However, the question would be, how would a policy already in effect be enforced? Should the system be modified to prevent this step from being skipped? If so, then the question of cost to modify becomes an issue. There must be some cost-benefit analysis to determine if the money invested to rewrite the requisitioning software will be recouped after launch. Some type of integration between the RRAM system and the requisitioning system must be created for this option to be truly effective.

Perhaps changing the policy for requisitioning can make the current system more effective. By changing the RRAM query from the ALS to the Fleet and Industrial Supply Center (FISC), the policy can be enforced. But reassignment of responsibility only solves the issue if the part cannot be fulfilled by stock carried on the ALS. This policy change would not affect parts that can be filled by stock located on the ship.

\section{B. TRYING TO IDENTIFY}

Trying to identify stock on ALS that is excess is a cumbersome and wearisome job. Currently, there are configuration management validation teams who perform this function during Integrated Logistics Overhauls, which coincide with an ALS' overhaul period. During this time, the Consolidated Shipboard Allowance Listing (COSAL) is validated against actual equipment installed (NAVSUP P-485, 2005, p. 2099.3). Often, due to time constraints and manning issues, the validation is completed on only a small percentage of the systems installed on the ship. These tend to be the more common, 
high-visibility systems, which means the less-seen systems are often never validated. Those parts associated with these systems can remain on the ALS for years-never being issued or even necessary.

By focusing more on equipment validation, ALS personnel can begin to reduce the amount of excess material on each individual platform. This must be a concerted effort between the Supply Officer, the supply personnel and the COSAL managers. Careful validation of each major system can ensure all aspects of the system have been validated and the correct parts necessary for their repair are stocked onboard.

Getting Commander, Naval Surface Forces, involved in the validation may be another viable avenue to identifying excess material on the ALS due to incorrect COSAL or non-demand items. The Commander can develop a schedule to aid the ALS in completing all validations over a three-year period. By putting the actual validation schedule at a level above the individual ALS, the process can continue on a set timeline despite transfers and turnovers. The process can follow the schedule because each validation is independent of the others. There would also be no confusion over what had been validated and what had not.

\section{WEB PORTALS}

Web portals are gateways to a set of programs and/or databases that can be accessed via a single entry point or "portal.” Once the user has been authenticated, they can access any of the linked areas connected to the portal gateway. A simple and widely known example of this is myYahoo.com, which allows a validated user access to e-mail, personal pages, and news stories specific to their location-to name only a few options. They also set the stage to develop collaboration areas where users in different locations can "meet" to work on projects as if in the same conference room.

Web portals allow information to be managed in a revolutionary manner. Instead of information being used to determine if a business plan is feasible, it is being used to actually shape the strategy of future business plans. By allowing a seamless environment for information to flow across all levels both vertically and horizontally, decisions are 
made faster, more distinctly and with better results. This information sharing is the pivotal piece to allowing industry to expand into areas previously not possible due to lack of knowledge.

In Figure 11, we see how the position of information management is critical for ensuring the associated processes are accurate. Improper handling of the information creates a system of errors and unreliable data that will be counterproductive in achieving the organization's overarching goals.

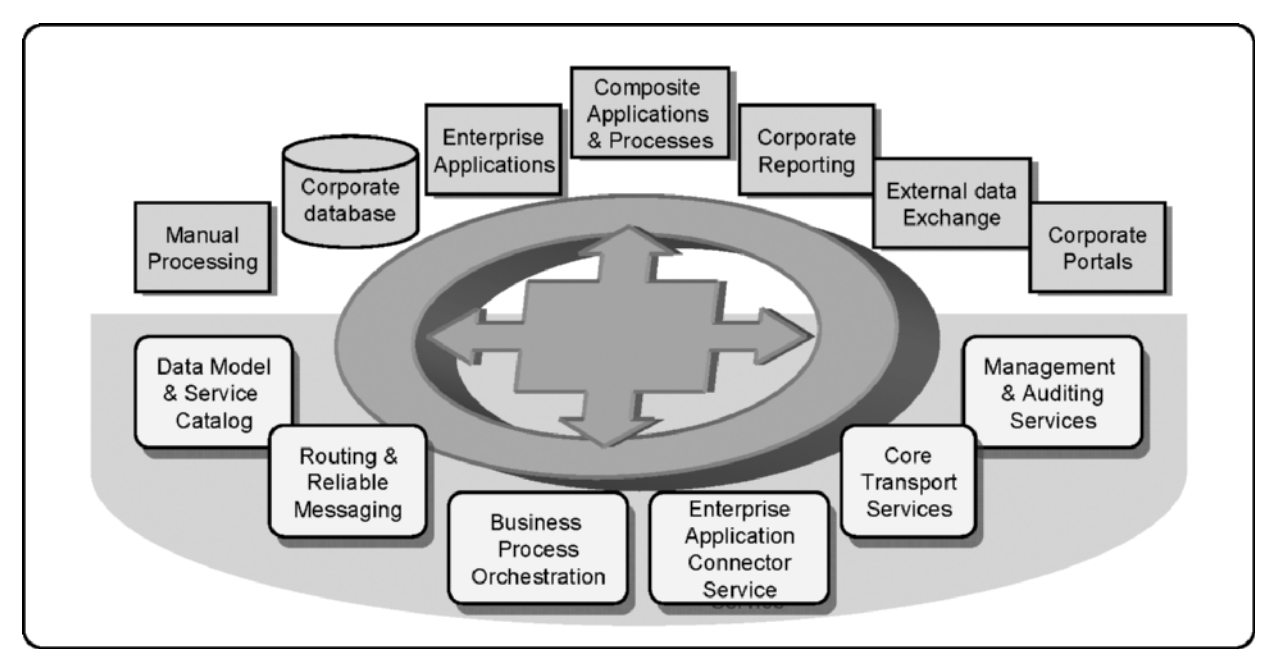

Figure 11. The Position of Information Management (From Chang, 2007)

Industry has taken this concept and streamlined the mechanics to allow clients and employees access to their network and links. The portals utilized in specific industries are commonly referred to as an Enterprise Web Portal (EWP). EWPs provide a single point of authentication for users who can then maneuver several different applications. Users can easily find, navigate, and manage information in a consolidated view, reducing in half the time necessary to accomplish tasks (Corporate Web Portals, n.d.). Utilizing EWPs allows users to customize their portals so links and pertinent information specific to their jobs are easily located according to their individual needs and desires.

EWPs have proven successful in managing very diverse inventory needs. They became mainstream in the mid-1990s as the most efficient model to manage libraries. It allowed universities to catalogue their resources as well as provide links to external 
resources in one centralized location requiring users to authenticate only one time. A prime example is the NPS Dudley Knox Library website that provides multiple sources for research accessible in one location. The system provides access to the physical books inside the library, multiple electronic databases to which the school subscribes, and even the inventory of regional libraries for books that are available for an interlibrary loan. Amazon.com has used EWPs to manage not only its inventory, but also to provide the inventories of collaborating sellers via its website. The portal maintains a listing of past purchases and searches for individual users and uses this information to make suggestions of possible items of interest when users log into their personal portal gateway. It is this advanced inventory management design that should be utilized to aide in the reduction of excess material.

RRAM has been in effect since 2002. As stated earlier, it was a commercial-offthe-shelf product implemented to improve asset visibility and reduce excess material. However, the search parameters in RRAM require ALS customers to enter only one line item at a time. With ALS often experiencing limited connectivity, this can become a tedious and unrealistic option.

By utilizing an EWP to provide ALS users access to excess material, they can gain access to not only that material held in the RRAM inventory, but to the other ALS inventories that have been linked to the system to show availability when parts are queried. Currently, users must access a separate system to view the inventory of other ALS, which requires more work time and connection time. EWP can be configured to allow batch processing of requests, which can significantly reduce the amount of dataentry required by ALS personnel, as well as reduce the amount of time necessary to maintain a connection with the EWP.

EWP can also allow suggestions to be offered to users when searching for parts. Take, for example, an ideal situation on an ALS where this technology could aide in reducing excess material. A user enters into the portal the part they need based on the job requirements. There are no available parts on the ship, so a request must go into the logistics system for fulfillment from an outside source. By utilizing the suggestion option of the EWP, all databases can be searched for an interchangeable part that is perhaps 
already in the ALS inventory but has been superseded by the current part on order. While the older part is still an acceptable part, it often becomes forgotten excess and consumes the limited space available.

Implementation of an ALS EWP opens the way to link many Defense Logistics Agency (DLA) databases onto a single source website. Currently, DLA utilizes a web portal called Logistics Toolbox. This portal, however, requires different passwords for different areas. In the end, users either forgo using the site because of the multiple registration processes necessary to gain access, forget passwords, or worse, write the passwords down near their terminals. Through deployment of an ALS EWP, users are required to register one time for all necessary applications. Once approved for access, their portal will display only the areas they have been granted access.

Web portals can provide a degree of integration that is not present in the present logistic/RRAM system. Having an intelligent system that not only scans excess material levels but offers suggestions for substitutions from excess material provides a level of support not currently available to the individual. Web portals provide the opportunity to create a system that automatically connects to several databases to complete the tasks of searching for excess material.

\section{POSSIBLE ISSUES TO THE SUCCESS OF PORTALS}

\section{Obsolete Parts}

When systems are updated across all ALS platforms, parts associated with the earlier systems become unnecessary or obsolete. These parts cannot be used by any of the ALS platforms and, therefore, will not be reduced through the increased visibility provided by portals. If systems are only updated on particular ALS platforms, the excess parts could be significantly reduced by the increased visibility to the platforms that still require the parts. The portal will provide a higher level of visibility to the platforms that no longer require the parts when those that do require requisition. 


\section{Systems Sold to Foreign Navies}

The Navy does sell superseded weapons systems to foreign allied navies. If the excess material found on ALS is associated with these systems, use of portals will only help reduce the excess inventory if we allow the foreign navies limited access to the portal. By allowing limited access, the foreign navies will be able to order parts directly from the web for fulfillment by either shore side warehouses or ALS. If the parts are still on the ALS, they would simply be transferred to the local FISC for further transfer to their final destination. Once again, the EWP can make suggestions for alternate parts that may have been superseded but are still lingering in our supply system. However, if the foreign navy is not granted access to the EWP, the parts will remain useless to the current ALS and continue to consume our precious budgets through the cost to house and maintain the parts. 
THIS PAGE INTENTIONALLY LEFT BLANK 


\section{SUMMARY, CONCLUSION AND RECOMMENDATIONS}

\section{A. SUMMARY}

This research explored the possibility of utilizing web portals as an alternate approach to reduce and possibly eliminate excess material on Afloat Logistics Systems (ALS). A summary of Chapters I through IV is provided in the following paragraphs.

Chapter I is the introduction to the problem being presented and the goals of the paper.

Chapter II is the background of the Naval Supply System and the external partners involved in the operation of the system. There is a review on the basics of Supply Chain Management to include Just-in-Time inventory and Vendor-Managed inventory. There is a description of the two inventory methods using real-world examples from Dell and Walmart.

Chapter III included the definition of excess material, and how it applies to ALS. The issue of how ALS generates excess material, the current management of excess material, what is currently being done to reduce material on ALS, and why the current system is not working are addressed.

Chapter IV is the proposed solution to excess material. The explanation of web portals and their possible use in reducing excess material is addressed in this chapter. How the current system could be improved along with the explanation for the choice of utilizing web portals is reviewed.

\section{B. CONCLUSION AND RECOMMENDATIONS}

The need to reduce and eliminate excess material on Afloat Logistics Systems (ALS) is more prudent now than ever before. With defense budgets being reduced and personnel manning being scrutinized and overhauled (e.g., Littoral Combat Ships), it is imperative the U.S. Navy gets the issue under control. This paper aimed to show how web portals might be the answer to this issue. By developing a one-stop shopping experience for ALS personnel, web portals could provide not only the potential for excess 
material screening automatically, but could even screen for alternate parts that could satisfy the ALS requirement from excess material.

While not specifically addressed in this paper, it is clear the ALS needs to begin a significant shift from the practice of hoarding and bulk-loading parts for potential failures while away from homeport. Instead, the focus should be on utilizing the tremendous supply chain already established between Naval Supply Systems Command, Defense Logistics Agency, Naval Inventory Control Points and the Fleet and Industrial Supply Centers. Based on my experience, the amount of parts carried on ALS are often more than necessary and are huge space hogs-space that is often hard to come by and better utilized for other purposes (e.g., force protection gear storage).

Based on the research completed during this project, I have determined transition to total use of web portals may be difficult for the ALS for two main reasons. The first reason is the connectivity will continue to be a problem on the ALS. Right now, if the connectivity goes down, orders for parts can always be sent via radio transmissions. While excess material options cannot be checked in the Realtime Reutilization Asset Management (RRAM) System, parts can still be ordered. If the entire ordering process is web-based, a loss in connectivity could spell potential disaster for an ALS in the middle of the ocean. The second reason is coordination between existing systems and the commands involved in running those systems. The systems already in place are not user friendly and certainly are not going to be plug-and-play with web-based software. The potential to have any of the main commands relinquish control over any area of their operation in an environment where everyone is vying to prove his necessity will be a daunting task.

However, parts of web portal technology could be implemented in the existing systems. Using the concept of a main shopping page a web portal could be easily created and securely implemented with very little initial investment. Slowly, the existing RRAM and Defense Reutilization and Marketing Organization databases can be linked to the web portal, allowing the ALS to access during periods of connectivity. 


\section{RECOMMENDATIONS FOR FURTHER RESEARCH}

This paper has shown that while in theory web portals could provide an invaluable integration tool for reducing and eventually eliminating excess material, it is not a practical solution for the moment. The following are recommendations for further research:

1. Conduct a detailed analysis on the top 1000 small dimension parts with a demand of more than 4 per week and the top 100 large dimension parts with a demand of more than 1 every two weeks on the ALS to determine which parts should be continuously stocked. All other items should be ordered and shipped to the ALS utilizing the supply chain already in existence. There will be very few times an ALS will go more than two weeks without receiving a replenishment of fuel, food or stock. Holding parts on an ALS simply because the Consolidated Shipboard Allowance Listing (COSAL) suggests carrying the part is no longer a smart or logistically sound practice.

2. Develop a database system that can automatically integrate excess material record from ALS to determine actual line item descriptions of excess material. One of the issues encountered during this research was the lack of information regarding the breakdown of excess material classification. It would be interesting to know exactly what the excess material classification items are. This information would allow us to determine whether the excess material was a product of systems no longer in use on the ALS, whether they are a result of inconsistent COSAL levels, or whether the level is simply a product of improper ordering procedures. 
THIS PAGE INTENTIONALLY LEFT BLANK 


\section{LIST OF REFERENCES}

Atknison, C. (2005). Dell computers: A case study in low inventory. Retrieved from http://www.inventorymanagementreview.org/2005/09/dell_computers_html

Beer Distribution Game. (n.d.) Retrieved February 6, 2011, from http://www.business.reachinformation.com/Beer_distribution_game.aspx

Cetinkaya, S., \& Lee, C. (2000). Stock replenishment and shipment scheduling for vendor-managed inventory systems. Management Science, Vol. 46, No. 2 (Feb., 2000), pp. 217-232.

Chang, W. (2007). Network-centric service-oriented enterprise. AA Dordrecht, The Netherlands: Springer.

Chopra, Sunil, \& Peter Meindl. (2001). Chapter 1 in Supply chain management: strategy, planning, and operations. Upper Saddle River, NJ: Prentice-Hall.

Corporate Web Portals. (n.d.). Web portals 101. Retrieved December 15, 2010, from http://www.webportal101.com

Council for Supply Chain Management Professionals (CSCMP) website. (2011). http://cscmp.org/aboutcscmp/definitions.asp

DeAngelis, S. (2011, January 10). Defining the supply chain [Entry Post]. Enterprise Resilience Management Blog [Weblog]. Retrieved January 25, 2011, from http://enterpriseresilienceblog.typepad.com/enterprise_resilience_man/2011/01/de fining-the-supply-chain.html

Defense Acquisition Guidebook. (n.d.) Defense Acquisition University website. Retrieved January 19, 2011, from https://acc.dau.mil/CommunityBrowser.aspx?id=314716\&lang=en-US

Disney, S. (2009). Bullwhip effect in supply chains. Retrieved November 15, 2010, from http://www.scitopics.com/Bullwhip_Effect_in_Supply_Chains.html

DLA Logistic Information Service. (2010). The national stock number, the gear that keeps the supply chain running. Retrieved January 23, 2011, from http://www.dlis.dla.mil/PDFs/NSN.pdf

DOD 4140.1-R. (2003). Office of the Deputy Secretary of Defense for Logistics and Materiel Readiness. Washington, DC. 
DOD Supply chain management: Can the department identify and meet its supply needs efficiently? Hearing Before the Panel on Defense Acquisition Reform of the Committee on Armed Services House of Representatives, Senate. 111th Cong., 2 (2009)

Einstein, A. (n.d.). Great-Quotes.com. Retrieved December 25, 2011, from GreatQuotes.com website: http://www.great-quotes.com/quote/335

Evanko, P. (2010). Vendor-Managed Inventory. HVACR Distribution Business 32-35. Business Source Complete, EBSCOhost. Retrieved January 22, 2011, from http://hvacrdistributionbusiness.com/mag/vendor-managed-inventory-1210/\#

Federal Reserve Bank of Dallas. Supply Chain Management. (2005). Retrieved January 22, 2011, from http://www.dallasfed.org/research/indepth/2005/id0501.html

Frahm, S. (2003). Vendor managed inventory (VMI): Three steps in making it work.” Retrieved January 24, 2011, from http://scm.ncsu.edu/public/lessons/less030305.html

Ganeshan, Ram, \& Terry P. Harrison. (1995). An introduction to supply chain management. Department of Management Sciences and Information Systems, 303 Beam Business Building, Penn State University, University Park, PA

German Academic Society for Production Engineering. (2010). Planning and realization of an innovative airline catering production plant: industrial case study. Munich, Germany: Gschirr, M.

Global Text Project. (2010). Securing and managing external relationships: Strategies for external relationships. Retrieved January 25, 2011, from the Connexions website: http://cnx.org/content/m35469/1.4/

Higuchi, T., \& Troutt, M. (2008). Life cycle management in supply chains: identify innovations through the case of the VCR. Hershey, PA: IGI Publishing.

Hines, T. (2004). Supply chain strategies: Customer driven and customer focused. Oxford, UK: Elsevier.

History of Defense Logistics Agency. (n.d.). DLA website. Retrieved February 5, 2011, from http://www.dla.mil/history/history.aspx

Hugos, M. (2002). Essentials of supply chain management. Hoboken, NJ: John Wiley and Sons, Inc.

Iba, N. (2009). Supply chain of dell. Retrieved January 17, 2011, from http://www.authorstream.com/Presentation/vivek259-194330-supply-chain-dellentertainment-ppt-powerpoint/ 
Jones, P. (2007) Flight-Catering, in Becker, H, \& Grothues, U., Cateringmanagement portrait einer wachstumsbranche in theorie und praxis (chap. 1.4.1, pp. 39-55). Behr'sVerlag: Hamburg.

Lambert, D. M., Stock, J. R., \& Ellram, L. M. (1998). Fundamentals of logistics management. Boston, MA: Irwin/McGraw-Hill, Chapter 14

Ligus, R. (2010). Supply chain management. Retrieved November 18, 2010, from http://rockfordconsulting.com/supply-chain-management.htm

Magretta, J. (1998). The Power of virtual intergration: An interview with Dell computer's Michael Dell. Harvard Business Review, 76(2), 72-84. Retrieved from EBSCOhost.

Mentzer, J. T., et. al. (2001). Defining Supply Chain Management in Journal of Business Logistics, 22(2), 2001, pp. 1-25.

NAVSUP P-485. (1997). Naval supply systems command. Mechanicsburg: NAVSUP.

Total Asset Visibility Systems. NAVSUP website. (2010). Retrieved November 18, 2010, from https://www.navsup.navy.mil/navsup/ourteam/navsuphq/04/logistics_systems/Tot al\%20Asset\%20Visibility\%20Systems

North Carolina State, Supply Chain Resource Cooperative home page. (2011). Retrieved January 17, 2011, from http://scm.ncsu.edu/public/inventory/

Reisinger, D. (2009, March 20). Nintendo Wii supply finally catches up to demand. Retrieved February 7, 2011, from http://news.cnet.com/nintendo-wii-catches-upto-demand

Shukla, I. (2010). Just in time inventory. Retrieved January 23, 2011, from http://www.buzzle.com/articles/just-in-time-inventory.html

Toyota Global. Toyota Production System. (n.d.). Retrieved January 22, 2011, from http://www.toyotaglobal.com/company/vision_philosophy/toyota_production_sys tem/

The U.S. Navy Fact File. Retrieved September 17, 2010, from http://www.navy.mil/navydata/fact_display.asp?cid=4200\&tid=1300\&ct=4 
THIS PAGE INTENTIONALLY LEFT BLANK 


\section{INITIAL DISTRIBUTION LIST}

1. Defense Technical Information Center

Ft. Belvoir, Virginia

2. Dudley Knox Library

Naval Postgraduate School

Monterey, California 